\title{
Attitudes toward Abortion for Medical and Non-medical Reasons among the Turkish Second Generation in Europe - The Role of the Family and Societal Contexts*
}

\author{
Nadja Milewski, Sarah Carol
}

\begin{abstract}
This paper studies attitudes toward abortion among the second generation of Turkish migrants and their native counterparts in six western and northern European countries. We focus on Turkish migrants because they not only constitute one of the largest immigrant groups, but are also hypothesised to be culturally and demographically very distinctive from the native group. We used data from the project on "The Integration of the European Second Generation (TIES 2007-08)" from Austria, France, Germany, the Netherlands, Sweden and Switzerland. The sample consisted of 4,761 respondents aged 18 to $35,49.5$ percent of whom were children of Turkish migrants born in Europe and 51.5 percent belonged to the respective non-migrant comparison groups. Unlike in other surveys, the question regarding attitudes toward abortion in the TIES questionnaire distinguished between "medical" and "non-medical" reasons for abortion, with the possible answers being "never", "in specific cases" and "always". We carried out multinomial logistic regression analyses and investigated three research questions: 1) Departing from assimilation theory, we examined whether the attitudes of migrant descendants differed from those of their non-migrant counterparts. Our results show that both groupings under study expressed a range of attitudes, and that abortion for medical reasons was more accepted than abortion for non-medical reasons. However, second-generation Turks were more likely than the natives to say that they would never accept abortion. 2) We investigated the extent to which the societal climate and the integration context of the respondents influenced their attitudes toward abortion, while assuming that we would find cross-country variation in these attitudes. Our results reveal that among natives, levels of acceptance of abortion are lowest in Germany and highest in Sweden and France. We found a similar country pattern for women and men of the second Turkish generation. 3) We explored the degree to which the respondents' family contexts (childhood backgrounds as well as current socio-demographic variables) influenced their attitudes toward abortion. While these factors
\end{abstract}

\footnotetext{
This article belongs to a special issue on migrant fertility.
} 
partially explained the variation within the Turkish second generation and within the native comparison group, the country differences remained significant. We conclude that attitudes toward abortion in the Turkish second generation are influenced by their family backgrounds, but also by their socialization experiences in European receiving countries. These findings suggest that cultural assimilation processes are occurring, but not to the point where the attitudes of migrant descendants have converged with the attitudes of natives in the respective destination country.

Keywords: Abortion · Attitudes · Second generation · TIES · Turkish migrants

\section{Introduction}

With recent political shifts, the topic of abortion appears back on the agenda in European public debates. As we still lack sufficient knowledge of the determinants of attitudes toward abortion, particularly in the face of migration (Rydgren 2005), our paper studies attitudes toward abortion among the second generation of Turkish migrants living in six western and northern European countries and the respective native majority group members.

The demographic behaviour and the structural and cultural integration of Turkish migrants and their descendants in Europe have been intensely studied (Kulu/ Gonzalez-Ferrer 2014). This research interest has been explained by demographic characteristics of this group: it is a large group; its members live in almost all western European countries; and its members come from a country that has entered the second demographic transition later than western European countries (van de Kaa 1987). The family demographic patterns and the religious backgrounds of Turkish migrants differ from those of European non-migrant populations (e.g. Nauck 1997; Milewski 2007, 2010a/b, 2011; Garssen/Nicolaas 2008; Cifuentes et al. 2013; Krapf/ Wolf 2015). While the fertility behaviour of Turkish migrants and their descendants has received considerable scholarly attention, reproductive health as one aspect of family planning among migrants remains an understudied subject. Little is known about international migrants' family planning, reproductive health practices or attitudes toward induced abortion (Carol/Milewski 2017; Agadjanian/Yoo 2018) - in part because these topics are sensitive, and therefore hard to study (Bankole et al. 1998). Thus, the study of attitudes toward abortion is relevant from a demographic perspective, but also from the perspective of assimilation theory. As an indicator of cultural integration, these attitudes are most resistant to change along with family and gender values (Norris/Inglehart 2012). Therefore, we attempt to explain these attitudes focusing on Turkish descendants in Europe.

There is considerable cross-country variation in the prevalence of induced abortion as well as in the norms towards it. Many immigrant groups in Europe originate from the MENA region and neighbouring countries with above or close-to replacement fertility, such as Turkey. On the one hand, patriarchal family systems and high- 
er levels of religiosity foster anti-abortion norms in these countries (Norris/Inglehart 2012). On the other hand, the acceptance, availability and usage of contraceptives are lower in these countries than in Europe (Haub 2007; Ribbert 2009; Helfferich et al. 2011). Hence, in some of these migrant-origin contexts, abortion may be the sole - though not always legal - method of birth control (Bankole et al. 1998); and the prevalence of abortion may be higher than in Western Europe - despite lower levels of acceptance (Sedgh et al. 2016).

Regardless of the actual abortion practices of a population, people's attitudes toward abortion can be framed from different perspectives. As these attitudes reflect norms regarding life and death and the rights of the unborn, they are highly intertwined with religiosity. In addition, because views on abortion touch on the question of women's self-determination, they reflect norms regarding gender equality and sexual liberalisation. Moreover, they trigger questions about state interference in individual decisions (Gerhards/Rucht 2000).

For international migrant groups, attitudes and values regarding gender equality, marriage, fertility and sexuality are indicators of cultural assimilation processes (Kalmijn/Kraaykamp 2017). As many immigrant groups in Europe originate from countries that differ from Europe in their prevailing attitudes toward religion, gender equality and sexual liberalisation (Norris/Inglehart 2012), these indicators are central to debates about immigrant integration in Europe (Koopmans 2015).

Studies of Turkish migrants have shown that they tend to transmit the culture of origin across generations. Moreover, compared to their non-migrant counterparts, Turkish migrants maintain higher levels of religiosity (e.g. Van Tubergen/Sindradóttir 2011), are less likely to promote gender equality (e.g. Röder 2014), and have higher fertility rates (Kulu/González-Ferrer 2014). These findings suggest that the second generation should also differ considerably from the majority population at destination in their attitudes toward abortion, i.e. they should be less likely to accept abortion. However, assimilation theory would lead us to expect that attitudes toward abortion in the second generation would resemble those of natives (Gordon 1964). Educational achievement, which is considered a driver of integration in other life domains, is usually higher in the second than the first generation (Alba et al. 2011). Having a higher education is typically associated with having more egalitarian values (Röder/Mühlau 2014), using contraception and engaging in family planning - behaviours that may in turn be linked to increased acceptance of abortion (e.g., Milewski 2011; Helfferich et al. 2011).

To investigate these contrasting perspectives, we employed data from the project "The Integration of the European Second Generation (TIES 2007-08)", which targeted Turkish migrant descendants of the second generation, i.e. those children who were born in the country of destination to one or two immigrant parents from Turkey. The countries of residence included in our sample are Austria, France, Germany, Sweden, Switzerland and the Netherlands. We investigated three research questions: 1) Departing from assimilation theory, we asked whether the attitudes toward abortion of Turks belonging to the second generation differed from those of their native-born counterparts. 2) Based on the assumption that the country of residence and its institutional context, policies and cultural norms affect the inte- 
gration processes of immigrants and their descendants, we tested the role of the societal climate (A/mond/Verba 1989) and the integration context (Crul et al. 2012) by examining cross-country variation in attitudes toward abortion. 3) We explored to what extent the characteristics of the context of the current family and of the family of origin can explain individual- and group-level attitudes toward abortion. Previous research mainly captured the current situation of the respondents (Carol) Milewski 2017).

In addition to addressing a rarely researched topic, our study contributes to the literature by using two dependent variables: namely, medical and non-medical reasons for abortion. The majority of previous surveys and studies tended to ask more about attitudes in general, thus producing bias. The answers in the TIES survey were not collected on a continuous scale, but in three categories. This approach allowed us to depart from the common practice of analysing the mean when attitudes are measured on a metric scale. Previous authors have argued that the distribution in attitudes toward abortion may have changed despite a rather stable mean over the decades (Jelen/Wilcox 2003). Thus, our study can produce a much more differentiated picture based on the reason for abortion for both study populations.

\section{Theoretical background}

In the following sections, we will outline our arguments as to why migrants and natives might differ in their attitudes toward abortion. In order to explore potential group differences, we draw attention to the reasons for abortion (Section 2.1). While abortion on the basis of medical reasons is widely granted, including in immigrants' countries of origin (Shapiro 2014), non-medical reasons are more contested. We therefore expect that the divide between natives and descendants will be strongest in the case of abortion for non-medical reasons. The main mechanisms explaining the preservation of restrictive attitudes toward abortion are ethnic and religious socialisation and the transmission of values through parents originating in Turkey (Section 2.2) and religious institutions (Section 2.4). However, counterinfluence might stem from the country of residence (Section 2.3) where persons of Turkish origin have attended school and where they have been exposed to a different socio-political climate with regard to abortion. According to assimilation theory, they should hold attitudes that resemble those of natives. Accordingly, the gap between descendants and natives should be small. We will elaborate on these contrasting perspectives in the following sections.

\subsection{Reasons for abortion}

Previous studies on attitudes toward abortion have found large differences across regions. People in the Arabic countries of Asia and North Africa are less likely to approve of abortion than people in Western Europe and North America (Adamczyk 2013; Jelen/Wilcox 2003; Jelen 2014; Bahr/Marcos 2003), even though abortion rates are higher in the former than in the latter group of countries (Sedgh et al. 
2016). These broad regional differences are associated with different religious traditions, which are in turn correlated with gender equality and sexual liberalisation. People living in Western, largely Christian societies express more support for gender equality and sexual liberalisation than people living in Muslim-majority countries (Norris/Inglehart 2012). Among Muslim countries, Turkey has relatively liberal abortion policies. Nonetheless, the legality of induced abortion in Turkey depends on the timing and type of abortion being sought, as well as the reasons for the abortion (Loeber 2008).

Even in Europe, individual attitudes and societal norms do not always foster tolerance of abortion. However, most developed countries have policies that allow induced abortion under certain circumstances. While social reasons for seeking an abortion are permitted, in most cases the woman seeking an abortion must give a medical/physical reason for an abortion, such as a serious threat to her physical or mental health. The social reasons a woman seeking an abortion can cite include that her family does not have enough money to support a (or another) child, that the child would be illegitimate, that she is under 16 years of age, or that the pregnancy resulted from a sexual crime. Often, the reason given for the abortion depends on the duration of the pregnancy, as the legal time frame for seeking an abortion for medical reasons is longer than the legal time frame for seeking an abortion for social reasons (Levels et al. 2014; Clements 2015; Ankara 2017).

Just as national policies differentiate between medical and non-medical reasons for abortion, individuals also differentiate between these reasons in their attitudes toward abortion. Clements (2015) reported that in a survey conducted in Great Britain in 1993, levels of approval of abortion varied greatly depending on the reason for the abortion. Relatively small percentages of respondents said they disapprove of abortion in cases in which the health/life of the mother was endangered by the pregnancy (ranging from 0 percent to 1 percent among Protestants to 9 percent among Roman Catholics), and when the foetus was at risk of deformation (3 percent to 22 percent). By contrast, much larger percentages of respondents said they disapprove of abortion for social reasons, such as financial constraints (39 percent to 65 percent). For the US, Bumpass (1997) investigated how the design of such surveys - i.e. the phrasing and the order of the questions - influenced the responses. Overall, however, he also found that around 80 percent of respondents said they approve of abortion for limited reasons only: namely, if the woman's health is endangered, if the foetus has a serious impairment, or if the pregnancy resulted from rape. In line with Clements' (2015) findings, he reported that only 41 percent to 46 percent of respondents said they approve of a woman having an abortion because she wants no more children, has financial constraints, or is unmarried (i.e. for more inclusive reasons); and that slightly smaller percentages of respondents agreed that a woman should be able to obtain an abortion for any reason at all (Bumpass 1997).

Unfortunately, most (cross-nationally comparative) datasets do not assess attitudes in such a detailed fashion, or they present the information in a summary scale (Rosenhouse-Persson/Sabagh 1983). The study by Clements (2015) is an exception in differentiating attitudes toward abortion by reasons for the abortion. The focus of the vast majority of surveys and studies has been more on asking about attitudes 
in general, thus mixing different reasons and producing bias, and within-country variation by migrant background or ethnicity has hardly been considered in the previous literature.

\subsection{Migrant socialisation}

While natives and migrants alike are exposed to political socialisation in their countries of residence, it is not clear whether they are affected similarly or differently by it. On the one hand, we can assume that they are equally influenced. The approximation of cultural patterns, including the values of minorities and natives, is regarded as one indicator in a two-sided understanding of immigrant integration (Alba/Nee 1997). Classical assimilation theory would suggest that migrant generations gradually adopt the attitudes and behaviours of the natives at the destination (Gordon 1964). On the other hand, empirical evidence does not show such a clear pattern (A/ba/Nee 2003), and migrants and natives might be socialized differently. In their socialisation, compared to natives immigrant children can draw upon various resources, i.e. their ancestors' culture and that of the society at destination, which means that they are exposed in addition to political socialisation in their parents' countries of origin or their communities, parents or families that transmit values from their countries of origin. Women and men of subsequent migrant generations need to manoeuvre throughout their childhood and adolescence by choosing from or between elements of two cultural heritages under societal circumstances that may clash with these cultural traditions. Foner (1997) calls this process "bicultural adjustment." Previous literature has tended to portray the second generation as being "exposed to competing pressures" (Kalmijn/Kraaykamp 2017: 2), based on the assumption that the family of origin has more conservative values than the majority group in the destination country.

The findings on the demographic behaviour and the processes of structural and cultural integration among Turks in Europe are conflicting. Like other Muslim minorities, Turks lag behind in their socio-economic integration (Koenig et al. 2016) are more likely to be religious (e.g. Diehl/Koenig 2009; Jacob/Kalter 2013), and experience more discrimination than other migrant groups (Weichselbaumer 2016). The social distance between Turks and non-migrants is also relatively large (Sniderman/ Hagendoorn 2007). While we might expect to find that the second generation is better integrated than the first (e.g. Diehl/Koenig 2009; Van Tubergen/Sindradóttir 2011), it is also possible that attitudinal differences persist because of the intergenerational transmission of religiosity (e.g. Diehl/Koenig 2009; Jacob/Kalter 2013) or of norms, values and attitudes. There is also evidence that immigrants from Turkey in several European countries tend to maintain their family formation behaviour (i.e. number of children, early marriage and low rates of extramarital births) across generations (e.g. Milewski 2011; Baykara-Krumme/Milewski 2017). Only a few previous studies based on descriptive statistics have examined abortion practices among immigrants. These studies found that first-generation Turkish women in the Netherlands (Loeber 2008) and in Germany (Helfferich et al. 2011) have higher abortion 
rates than the majority group in the country of residence, in line with the differences in abortion rates between European countries and Turkey.

Regarding attitudes toward family and marriage, sexuality and gender equality, the previous literature has produced a diverse picture. While considerable variation within the immigrant groups persists, there is evidence that assimilation processes are occurring, but that a native-immigrant gap remains in the second generation. For example, Soeh/ (2017) found acculturation in attitudes toward homosexuality among immigrant descendants living in Europe, with levels of acceptance increasing with duration of stay and among the second generation. Kalmijn/Kraaykamp (2017) reported similar results for several attitudes toward marriage and sexuality.

With regard to attitudes toward abortion, Carol/Milewski (2017) found that immigrants from Muslim countries were less likely to accept abortion than members of the respective majority groups in several western European destinations. Controlling for socio-demographic characteristics and several indicators of religiosity, the study showed that attitudes toward abortion were even less tolerant among the second than the first generation.

Based on these considerations, we derive our first working hypothesis on the effect of the migrant background: We compare members of the second Turkish generation to their native counterparts, i.e. those who have non-migrant parents, and expect to find that the second generation are, on average, less accepting of abortion because of their socialisation in their ancestors' culture of Turkey, which has more restrictive abortion policies, less egalitarian gender values, lower levels of acceptance of abortion, and higher religiosity than European countries. We start to test this hypothesis for the whole sample of six countries, which compared the Turkish second generation on average to the natives' cross-country average in joint models. In addition, we estimate the group difference within each single country by preparing separate models for each country in order to check whether the second generation and the native comparison group show similar differences (if any) in each country. We distinguish between the reasons for abortion, and assume that the migrant-native gap in acceptance is smaller for medical reasons than for nonmedical reasons because the regulations regarding medical reasons are more similar between Europe and Turkey than those regarding non-medical reasons. In addition, we investigate in more detail the impact of the compositional differences of the groups under study. We assume that any differences between the second generation and the natives will decrease or vanish when we control for socio-demographic variables that mediate the effect of nativity status on attitudes toward abortion (sex, age, education). Additional variables that capture the respondents' individual characteristics are marital status and parenthood.

\subsection{European cross-country differences}

Our second working hypothesis concerns the influence of the countries of residence. Multiple studies have shown that policies can affect immigrants' integration (e.g. Goodman/Wright 2015), religiosity (Ersanilli/Koopmans 2011; Carol et al. 2015), union formation (Hamel et al. 2012; Carol et al. 2014), and fertility patterns 
(Andersson/Scott 2005; Milewski 2007). Moreover, in line with theories on political socialisation through school, work or the media (Almond/Verba 1989) we expect to find that the societal climate (e.g. the climate created by abortion policies and their implementation, and the general level of gender equality) influences the attitudes of a country's residents.

European countries share a rather long history where induced abortion has been subject to public and political discourses and to legislation. Abortion has been legal in the European countries included in our study since the 1970s at the latest. Despite their proximity, European countries have different histories and contents of abortion policies and permit different methods of abortion. ${ }^{1}$ Countries vary in the extent to which they allow abortion. For example, a woman may be permitted to seek an abortion if her life is at risk, if her physical or mental health is at risk, if she was raped, if there are foetal abnormalities, or if she is suffering from socio-economic deprivation or distress (Levels et al. 2014; see also Table A1 in the Appendix).

The cross-country variation in medical reasons for an abortion is smaller than the variation in non-medical reasons. Abortion to save a woman's life or to preserve her physical health is permitted in all of the countries included in our study. Abortion in response to foetal abnormalities is allowed in Austria, France and the Netherlands, but not in Germany, Sweden or Switzerland. Abortion for mental health reasons is permitted in Austria, Switzerland and Germany. Abortion on the grounds of a sexual crime is legal only in Germany (until week 12) and Sweden (until week 24). The woman's socio-economic circumstances are considered in Germany. Abortion for reasons of distress is legal in France, Germany, Switzerland (until week 12) and in the Netherlands (until week 22), but not in Austria and Sweden (Levels et al. 2014).

Germany ranks as the most tolerant country in terms of the number of legal grounds for abortion. But the Netherlands may be the least restrictive country overall because a woman is permitted to have an abortion on the grounds of distress - which encompasses several reasons - until relatively late in her pregnancy. The countries also vary in the implementation of these policies. Despite the rather large number of legal grounds for abortion, Germany is clearly restrictive in the practice of abortion. For instance, the medical abortion pill (Mifepristone) is much harder to obtain in Germany than in other European countries, especially in France, Switzerland and Sweden (Arisi 2003). Also, women in Germany needed a prescription to obtain emergency contraception until 2015, while the morning-after pill has been widely available for a much longer time in Sweden, France, Austria and Switzerland than in Germany (ESHRE Capri Workshop Group 2015).

Scholars have frequently argued that feminism shapes abortion policies (Leve/s et al. 2014). Thus, the topic is often connected to gender equality. Just as there

1 Of the countries included in our sample, the Netherlands was the first to legalise abortion; in 1886 abortion became legal in order to save life. Austria, Germany and Switzerland followed in the 1930s. Abortion became legal in Sweden in 1946 and in France in 1955. Until the 1970s, medical reasons were the only grounds for legal abortion in these countries. Rape and distress were only subsequently introduced (except in Sweden and the former German Democratic Republic) (Levels et al. 2014). 
is cross-national variation in abortion policies, there is cross-national variation in gender equality norms. Among the countries included in our study, survey findings indicate that support for gender equality is highest in Sweden, followed by France; it is lowest in Germany, and it is moderate in the Netherlands and Switzerland (Norris) Inglehart 2012; Austria was not included here).

Compared to people in other countries with Muslim traditions, people in Turkey tend to express greater support for gender equality (Inglehart/Norris 2003; Norris/ Inglehart 2012). This stance on gender equality is also reflected in the regulation of abortion, which is less restrictive in Turkey than in other Muslim-majority countries (Hedayat et al. 2006; Loeber 2008; Shapiro 2014)

To our knowledge, there are only a few quantitative studies that have investigated attitudes toward sensitive topics like abortion and sexuality in international migrant groups across European receiving countries. Ersanilli (2012) examined various values, including beliefs about abortion, among Turkish migrants in several countries. The author also found less support for abortion in Germany than in France. Looking at attitudes toward abortion, Carol/Milewski (2017) found significant country variation across both the majority and the Muslim-minority populations, with those in France being the most accepting and those in Germany the least accepting of abortion. These findings suggest that the wider policy and societal climate as well as norms regarding gender equality may be better predictors of attitudes toward abortion than abortion laws.

Our study adds to the previous literature by focusing on the within-group comparison of second-generation Turks in six European countries. More importantly, we can differentiate between attitudes toward abortion for medical and non-medical reasons and draw on a retrospective measure of religiosity during childhood, which is superior to current religiosity. Based on the considerations outlined above, we formulated our working hypothesis on country variation as follows: We expect to find differences between the natives in the destination countries and between the individuals of the Turkish second generation living in these countries. More precisely, we expect to find the highest levels of acceptance of abortion in Sweden, the Netherlands and France; the lowest levels in Germany; and moderate levels in Switzerland and Austria.

\subsection{Family context and religiosity}

The third aspect we investigate in more detail are the within-group differences among the second generation and among natives. We focus on the main factors likely to affect attitudes toward abortion because they are related to gender equality, i.e. religiosity and variables associated with the family context. We include measures that refer to the family background and childhood of the respondents, as well as to their current living situations, in order to disentangle direct and indirect effects of the family background in the socialisation process on present-day attitudes of the migrant children (Kalmijn/Kraaykamp 2017).

Individual values and attitudes are mainly formed during a person's primary period of socialisation, with parents serving as models or direct instructors (Bandura 
1977). Alternatively, parents may indirectly influence the social contacts of their children by determining their educational paths (Bozon/Héran 2006). In addition, religious institutions are likely to influence attitudes toward abortion. The role of religion has been well documented in previous studies (e.g. Adamczyk 2013; Lewis/ Kashyap 2013). For example, religious institutions may cite religious scriptures that teach that life is given and taken by God alone, and that humans have no right to interfere in this process (Almond et al. 2013; Jelen 2014; Shapiro 2014). Although abortion is widely condemned by various denominations, levels of condemnation vary. Jelen (2014) found that disapproval is significantly higher among Muslims than among members of other denominations. Our data allow us to consider whether the respondents were raised in a religious family; and, for Muslims, whether they attended Koran lessons. Nevertheless, there is also significant opposition to abortion in Christian churches (Clements 2015). Thus, we expect to observe the lowest levels of acceptance of abortion among Muslims and Christians and the highest levels of acceptance of abortion among those without religious education.

We assume that the influence of religious education in childhood is mediated by the current level of religiosity. Religiosity can take different forms (believing, bonding, behaving and belonging (Saroglou 2011)), which have different influences on attitudes (Jelen 2014). Here, we consider answers to the question of whether religion is an important part of the respondent's life. We assume that highly religious people are less likely to approve of abortion than those who have no religious affiliation or see religion as unimportant (Carol/Milewski 2017).

Families with relatively high educational levels and status may be especially likely to transmit knowledge and goals that go beyond family formation, and may thus discourage (early) childbearing (Murphy/Wang 2001). In fertility research, findings on the influence of parental education have been mixed. It seems likely that the impact of the parents' education is mediated by the individual's own education (Baykara-Krumme/Milewski 2017). As an indicator of gender equality and the integration of the first generation, we use labour market activity of the mother when the respondent was aged 15 . We assume that if the mother was participating in the labour force, the respondent would have a higher degree of structural integration and more liberal gender attitudes, which would in turn be associated with greater acceptance of abortion.

Another family background variable we consider is the number of siblings. A higher number of siblings coincides with higher own fertility among Turkish women (Nosaka/Chasiotis 2010; Baykara-Krumme/Milewski 2017), which may suggest more conservative family values. Thus, we would expect to observe less acceptance of abortion if the family of origin was relatively large.

In addition, we use the presence of a third person at the interview as a control because it has been shown to bias the responses to sensitive questions. The type of third party present ranged from the parents of the respondents (mainly for those who still lived with their parents) to the partner or the children. Therefore, the thirdparty presence could be seen as reflecting the social control of the parents or the pressure to engage in social modelling. For example, a respondent who was inter- 
viewed in front of her/his spouse may have sought to appear to be conforming to the norm (Milewski/Otto 2017).

\section{Data, variables and methods}

\subsection{Data}

We analysed data from the survey "The Integration of the European Second Generation (TIES 2007-08)". ${ }^{2}$ TIES is a European comparative survey that targeted migrant descendants who were born in their parents' country of destination, i.e. the second generation. The survey was designed to specifically study the transitions of migrant youth during early adulthood, with a focus on school and work trajectories. Around 10,000 children of immigrants from Turkey, Morocco and the former Yugoslavia, as well as a native comparison group, were interviewed in 15 cities in eight European countries. An urban sample frame was chosen because most immigrants and their descendants throughout Europe live in cities. The sample size was approximately 500 respondents per city, with half belonging to the second generation and half belonging to the native comparison group. We selected Turks because they were sampled in seven of the eight countries, whereas the other two minority groups were sampled in a few countries only. Respondents were sampled as Turkish second generation if they were born in the country where the survey was held, and at least one of their parents was born in Turkey. The respondents were aged 18-35. A standardised questionnaire was used in the survey (Groenewold/Lessard-Phillips 2012). For our analyses, we selected all country datasets that included the Turkish second generation, as well as responses to the question on abortion. Our sample included data from 11 cities in six countries: Vienna and Linz in Austria, Paris and Strasbourg in France, Berlin and Frankfurt in Germany, Stockholm in Sweden, Zurich and Basle in Switzerland, and Amsterdam and Rotterdam in the Netherlands.

\subsection{Variables}

The last module of the TIES questionnaire contained a range of sensitive questions, including questions on attitudes and partnership history. There were two questions on abortion, which were introduced with a joint phrase: "Please tell me for each of the following statements whether you think it is always acceptable, acceptable in some specific cases, or never acceptable: ... abortion for medical reasons and abortion for non-medical reasons."

2 The TIES survey plays a pioneer role in data collections that allow the comparison of one or more origin groups in different destinations. Other projects, such as EURISLAM, do not contain such detailed information on attitudes toward abortion. Besides the age of the TIES data, we believe the uniqueness of the survey information is a reason to use it. 
Compared to qualitative in-depth interviews or special surveys on family planning and reproductive health (Bumpass 1997; Clements 2015), these two questions seem rather broad. For some respondents, the term "acceptable" may have captured such attitudes in general, while for others it may have referred to the question of whether abortion should be legal. Moreover, we cannot know how the respondents interpreted the term "medical reasons"; they may have thought about complications caused by the pregnancy for the mother, or about the health problems of the child, or both (Clements 2015). It is, however, unusual for a social science survey targeting international migrant groups to contain questions on family planning and reproductive health. Compared to the data from the general questions included in, for example, the EURISLAM survey (which sampled migrants from Muslim countries in several European destinations) about whether abortion was justifiable (Carol/Milewski 2017), the TIES data allow for a more differentiated analysis of such attitudes because they distinguish between "medical" and "non-medical" reasons. In addition, the answers were not collected on a continuous scale, but in three categories ( $1=$ "never acceptable", $2=$ "acceptable in specific cases", $3=$ "always acceptable").

Table 1 provides a descriptive overview of the variables used in the multivariate analyses by migrant status.

The first set of explanatory variables that are assumed to mediate the effect of the migrant status on attitudes toward abortion capture socio-demographic characteristics of the respondents at the time of the survey. "Marital status" distinguished between non-married and married individuals. Similarly, the "number of children" was combined to a dummy indicating parenthood. "Educational attainment" was measured using six categories that were constructed for a comparison across the TIES countries, which have different educational systems (Crul et al. 2012). It refers to the highest educational degree obtained. Because of the age structure of the sample, about a quarter of the respondents in both groups were still in education; in these cases, the education variable indicates the type of school attended. We then used an indicator for "religiosity". In the TIES survey, the respondents were asked to totally agree, agree, neither agree nor disagree, disagree, or totally disagree with the statement: "Being Muslim/Christian... is an important part of myself." We reduced these categories to three, and added another for respondents who did not indicate any religious affiliation.

The second set of variables takes into account variables of the respondents' family background and childhood. "Father's education" was made comparable across the destination countries and Turkey. We also employed the information about the "mother's labour market activity" when the respondents were aged 15. We recoded the original variables into two broad categories: "not active" were those who did not work outside the household (this captures the original answers working in the home or the family business) and "active" were those who had participated in paid employment at some point (i.e. employed, unemployed, or no longer working due to disability or retirement). For the "number of siblings", we used the categories "none," "1 or 2, " and " $3+$." The variable on "religious upbringing" is a combination of several questions. The respondents were asked whether they were raised ac- 
Tab. 1: Descriptive overview of the sample, by migrant status

\begin{tabular}{|c|c|c|c|c|}
\hline \multirow[t]{2}{*}{ Variable } & \multicolumn{2}{|c|}{$\begin{array}{l}\text { Native compa- } \\
\text { rison group }\end{array}$} & \multicolumn{2}{|c|}{$\begin{array}{c}\text { Turkish second } \\
\text { generation }\end{array}$} \\
\hline & $\mathrm{N}$ & $\%$ & $\mathrm{~N}$ & $\%$ \\
\hline \multicolumn{5}{|l|}{ Attitudes toward abortion } \\
\hline \multicolumn{5}{|l|}{ Acceptance for medical reasons ${ }^{* *}$} \\
\hline Never acceptable & 68 & 2.8 & 343 & 14.6 \\
\hline Acceptable in specific cases & 661 & 27.5 & 1072 & 45.5 \\
\hline Always acceptable & 1676 & 69.7 & 941 & 39.9 \\
\hline \multicolumn{5}{|c|}{ Acceptance for non-medical reasons ${ }^{* * *}$} \\
\hline Never acceptable & 346 & 14.4 & 1167 & 49.5 \\
\hline Acceptable in specific cases & 1093 & 45.4 & 817 & 34.7 \\
\hline Always acceptable & 966 & 40.2 & 372 & 15.8 \\
\hline \multicolumn{5}{|l|}{ Country of residence $e^{* * *}$} \\
\hline Austria & 467 & 19.4 & 441 & 18.7 \\
\hline France & 351 & 14.6 & 500 & 21.2 \\
\hline Germany & 503 & 20.9 & 503 & 21.3 \\
\hline Netherlands, the & 480 & 20.0 & 428 & 18.2 \\
\hline Sweden & 182 & 7.6 & 130 & 5.5 \\
\hline Switzerland & 422 & 17.5 & 354 & 15.0 \\
\hline \multicolumn{5}{|l|}{ Socio-demographic characteristics } \\
\hline \multicolumn{5}{|l|}{ Sex } \\
\hline Woman & 1256 & 52.2 & 1248 & 53.0 \\
\hline Man & 1149 & 47.8 & 1108 & 47.0 \\
\hline $\operatorname{Ag} e^{* * *}($ mean $)$ & 26,9 & & 24,4 & \\
\hline \multicolumn{5}{|l|}{ Marital status $* * *$} \\
\hline Not married & 1908 & 79.3 & 1539 & 65.3 \\
\hline Married & 492 & 20.5 & 816 & 34.6 \\
\hline Divorced & 5 & 0.2 & 1 & 0.0 \\
\hline \multicolumn{5}{|l|}{ Children in household *** } \\
\hline No & 1995 & 83.0 & 1696 & 72.0 \\
\hline Yes & 410 & 17.0 & 660 & 28.0 \\
\hline \multicolumn{5}{|l|}{ Education $* * *$} \\
\hline Primary & 31 & 1.3 & 88 & 3.7 \\
\hline Lower secondary & 172 & 7.2 & 434 & 18.4 \\
\hline Apprenticeship & 460 & 19.1 & 600 & 25.5 \\
\hline Upper secondary & 631 & 26.2 & 664 & 28.2 \\
\hline Tertiary & 1105 & 45.9 & 560 & 23.8 \\
\hline $\mathrm{mv}$ & 6 & 0.2 & 10 & 0.4 \\
\hline
\end{tabular}


Tab. 1: Continuation

\begin{tabular}{|c|c|c|c|c|}
\hline \multirow[t]{2}{*}{ Variable } & \multicolumn{2}{|c|}{$\begin{array}{l}\text { Native compa- } \\
\text { rison group }\end{array}$} & \multicolumn{2}{|c|}{$\begin{array}{c}\text { Turkish second } \\
\text { generation }\end{array}$} \\
\hline & $\mathrm{N}$ & $\%$ & $\mathrm{~N}$ & $\%$ \\
\hline \multicolumn{5}{|l|}{ Religion is important $* * *$} \\
\hline Agree & 356 & 14.8 & 1535 & 65.2 \\
\hline Neither nor & 173 & 7.2 & 171 & 7.3 \\
\hline Disagree & 151 & 6.3 & 80 & 3.4 \\
\hline $\mathrm{na} / \mathrm{mv}$ & 1725 & 71.7 & 570 & 24.2 \\
\hline \multicolumn{5}{|l|}{ Family background } \\
\hline \multicolumn{5}{|l|}{ Siblings ${ }^{* * *}$} \\
\hline None & 447 & 18.6 & 115 & 4.9 \\
\hline 1 or 2 & 1516 & 63.0 & 1183 & 50.2 \\
\hline $3+$ & 342 & 14.2 & 1035 & 43.9 \\
\hline $\mathrm{mv}$ & 100 & 4.2 & 23 & 1.0 \\
\hline \multicolumn{5}{|l|}{ Religious upbringing ${ }^{* * *}$} \\
\hline Christian & 1265 & 52.6 & 92 & 3.9 \\
\hline Muslim/no Koran school & & & 755 & 32.0 \\
\hline Muslim/attended Koran school & & & 1118 & 47.5 \\
\hline Other religion or none & 1140 & 47.4 & 391 & 16.6 \\
\hline \multicolumn{5}{|l|}{ Father's education } \\
\hline Primary & 68 & 2.8 & 1046 & 44.4 \\
\hline Secondary & 1417 & 58.9 & 888 & 37.7 \\
\hline Tertiary & 785 & 32.6 & 210 & 8.9 \\
\hline $\mathrm{mv}$ & 135 & 5.6 & 212 & 9.0 \\
\hline \multicolumn{5}{|c|}{ Mother's labour market activity (respondent aged 15)*** } \\
\hline Not active (house wife) & 737 & 30.6 & 1109 & 47.1 \\
\hline Not active (unpaid work in family business) & 54 & 2.2 & 74 & 3.1 \\
\hline Active (unemployment/retirement/disability) & 78 & 3.2 & 138 & 5.9 \\
\hline Active (employment/enrolment in education) & 1474 & 61.3 & 927 & 39.3 \\
\hline $\mathrm{mv} / \mathrm{na}$ & 62 & 2.6 & 108 & 4.6 \\
\hline \multicolumn{5}{|l|}{ Third-person presence $* * *$} \\
\hline Yes & 437 & 18.2 & 708 & 30.1 \\
\hline No & 1786 & 74.3 & 1518 & 64.4 \\
\hline $\mathrm{mv}$ & 182 & 7.6 & 130 & 5.5 \\
\hline Total & 2405 & 100 & 2356 & 100 \\
\hline
\end{tabular}

Note: ${ }^{* *} \mathrm{p}<0.001$ via chi2 test for the association between the categorical variable/t-test for the metric variable and migrant status.

$\mathrm{mv}=$ missing values, $\mathrm{na}=$ not applicable.

Source: Own calculations based on TIES 2007-08. $N=4761$ 
cording to a certain religious tradition, and, if so, which. In addition, Muslims were asked whether they attended Koran lessons during their childhood. Although the questionnaire distinguished between several Muslim and Christian denominations, we combined them to form the categories "Muslim" for Turks and "Christian" for the natives because of the small numbers in most of the original categories.

Finally, we used the "presence of a third person" at the interview as a dummy (Milewski/Otto 2017; note that third-party presence was not included in the Swedish TIES questionnaire).

\subsection{Analytical strategy}

First, we address the hypothesis that attitudes toward abortion for medical and non-medical reasons differ between the Turkish second generation and the native comparison group. We give a descriptive overview of the attitudes toward abortion by type of reason, migrant background and sex (Fig. 1). We then present the results of the multivariate analyses based on multinomial logistic regression techniques ${ }^{3}$ for the whole sample and then for the six countries separately, comparing the second generation to the native comparison group (Fig. 2A and 2B; Table A2 in the Appendix). The results are displayed as average marginal effects (AME, Mood 2010).

In the second part, we focus on the cross-country comparison and within-group variation by carrying out separate models for the Turkish second generation and natives. A descriptive overview is presented in Figures $3 A-D$; followed by the multivariate models in Tables 2A and 2B (Fig. 4A-D). The objective here is to test our second working hypothesis on cross-country variation and the impact of the comparative integration context on the migrant group. If the country of residence plays a role in the attitudes of the migrant children, then they should exhibit a cross-country variation similar to that of the native comparison group across countries (a similar research design was employed to test this hypothesis e.g. in Milewski 2011).

In order to test our third hypothesis on the impact of the childhood and family background within the groups, the three groups of independent variables were used as controls; these are country of residence and sex, family background and childhood variables, current socio-demographic characteristics of the respondents as well as third-party presence at the interview.

\subsection{Sample and data quality}

Although the attitudes under study are of a sensitive nature, the response rates to the questions regarding attitudes toward abortion were rather good. For a compari-

3 Multinomial regression analyses was preferred over ordered logistic regression because the assumption of proportionality in the odds was violated (Brant test). A multinomial model allows an estimate of the differences in change between the answer categories, not the average change. 
son, Clements' study on Britain does not indicate non-responses; the percentages of respondents answering "don't know" ranged from about 3 percent to 11 percent (Clements 2015: 131-133). In our TIES sample, the non-response (including a small number of cases with non-valid responses) on attitudes toward abortion was about 11 percent. The share of non-responses did not vary much between the two reasons given; most of the respondents answered both questions, and only a few answered one question only. Therefore, we included all those cases in which the respondent answered both questions in our analyses. However, the non-response rates varied between the groups under study: with about 11 percent, the rate was almost twice as high among the Turkish second generation than among the native comparison groups (less than 6 percent). Moreover, there was some variation by country of residence: in France and Germany, the non-response rate was zero most likely because this module was a written questionnaire in these countries. The non-response or non-valid response rates in the other countries were moderate: below 3 percent in Austria, about 10 percent in the Netherlands, and about 15 percent in Switzerland. The highest non-response rates for attitudes toward abortion were in Sweden (about 38 percent in total, 27 percent among natives, and 47 percent among the second generation).

To check the data quality of the sample used, we compared the socio-demographic composition of the sample used $(\mathrm{N}=4,761)$ and the sample that only included the cases with non-responses and was not used in our analyses $(N=450)$. For both groupings, we found that the percentages of highly educated respondents and of respondents with no religious upbringing were slightly higher in the nonresponse group, which suggests that we may be underestimating the effects of higher education and secularism on attitudes. Given the otherwise high degree of compositional similarity between our sample and the non-response group and the high overall response rate, we are rather confident of the data quality in our sample. Our final sample consisted of 4,761 respondents, 49.5 percent of whom belonged to the second generation and 51.5 percent to the native comparison group.

\section{$4 \quad$ Results}

In the whole sample, abortion for medical reasons was more accepted than abortion for non-medical reasons (results not shown). Less than 9 percent of the TIES respondents said they would never accept abortion for medical reasons, whereas about 32 percent said they would never accept abortion for non-medical reasons. While 55 percent said they would always accept abortion for medical reasons, 28 percent said they would always accept abortion for non-medical reasons. For both reasons, more than one-third said they would accept abortion in specific cases.

By sex, we did not find significant differences in the attitudes in the whole sample. The only minor difference was that women would be slightly more likely to "never" accept abortion for non-medical reasons, but answer "in specific cases" more often than men. 
Fig. 1: Attitudes toward abortion, by reason, sex and migrant status $(\%)$
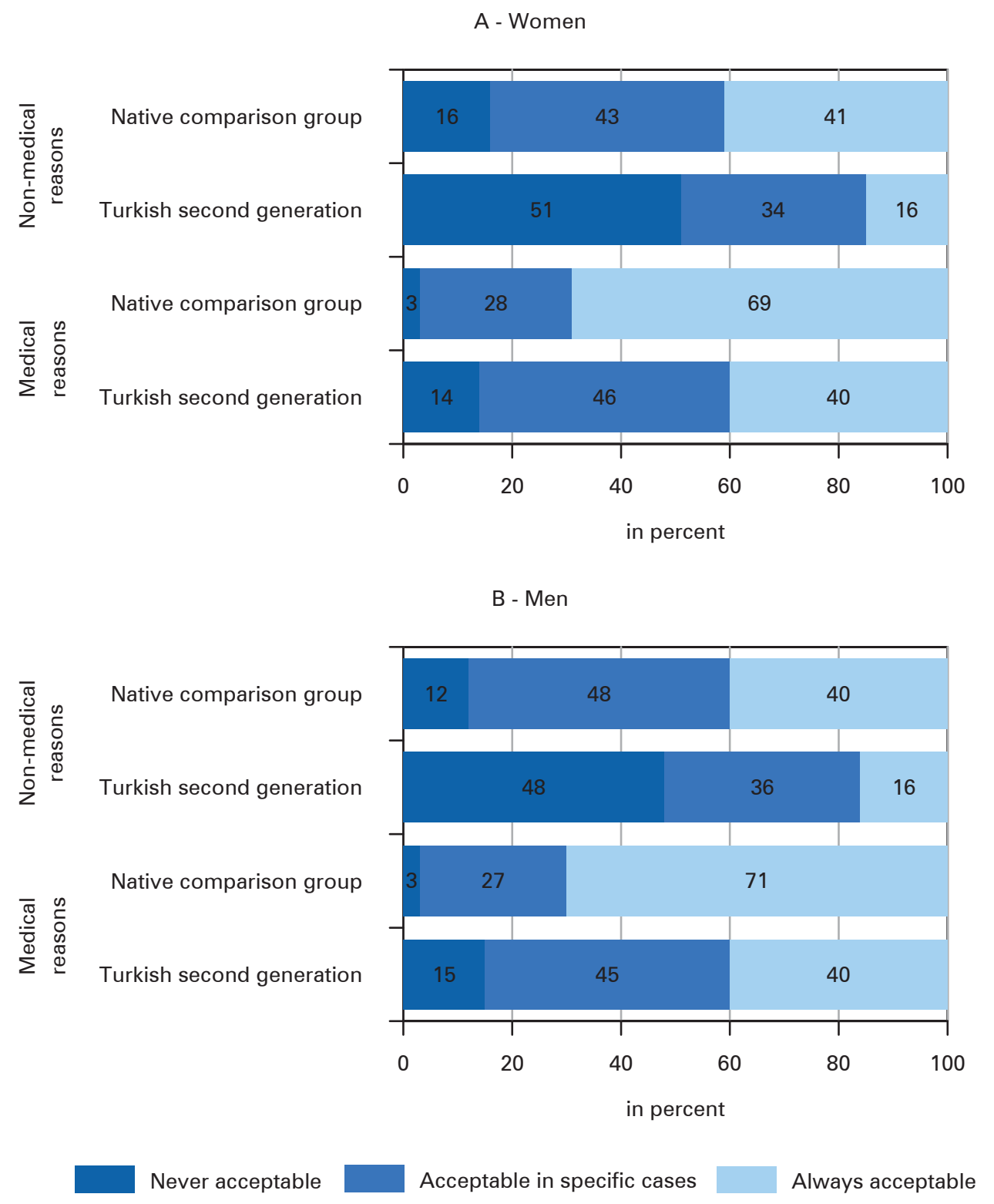

Source: Own calculations based on TIES 2007-08

\subsection{Migrant background and the reason for abortion}

We first test our working hypothesis of the migrant background, comparing the Turkish second generation to the native comparison group. 
For both reasons for abortion, we found large significant differences by migrant status, with persons of the second Turkish generation being less accepting (Fig. 1A for women and $1 \mathrm{~B}$ for men). Among women, just 3 percent of the native comparison group, but about 14 percent of the second-generation group, said they would never accept abortion for medical reasons. The percentage of those women who said they would never accept abortion for non-medical reasons was about 16 percent among the natives and 51 percent among the second-generation group. The rather low levels of disapproval of abortion among the natives suggest that the non-migrant populations in Europe have more liberal attitudes toward abortion than immigrants from Turkey, and particularly toward abortion for medical reasons. We should, however, keep in mind that the TIES sample is urban, and at least half of these country samples were drawn in the respective capitals. As inhabitants of cities have been shown to have more "liberal" values than those living in rural areas, the analysis may overestimate the acceptance of abortion among non-migrants. However, the low percentage of those who would never accept abortion does not imply a full acceptance of abortion, even for medical reasons. The attitudes among native women may be described as "plural": about 69 percent said they would always accept abortion for medical reasons, and 28 percent said they would accept it in specific cases; while 41 percent said they would always accept abortion for non-medical reasons, and 43 percent said they would accept it in specific cases.

Among the women of the Turkish second generation, the attitudes toward abortion were rather plural, too, but the acceptance levels were lower overall. This was not only because more respondents said they would never accept abortion, but also because fewer of these respondents said they would always accept it (40 percent for medical and 16 percent for non-medical reasons).

Compared to women, hardly any differences were found for men within either grouping. The finding of no-sex difference is consistent with the literature (Carol) Milewski 2017).

The overall differences between the Turkish migrant children and the native comparison group diminished in the multivariate analyses, but remained significant when analysing the whole sample of six countries (Fig. 2A and 2B as well as Table A2 in the Appendix show the marginal effects for Turkish descendants relative to those for the comparison group). With regard to abortion for medical reasons, the biggest difference was found in the category "always" acceptable. Individuals of the second Turkish generation were about 11 percentage points less likely to say they always accept abortion for medical reasons, and were 8 percentage points more likely to say they accept it in certain cases only (M.m3 in Tab. A2). By contrast, with regard to abortion for non-medical reasons, the biggest difference was that Turks were 10 percentage points more likely to say they never accept abortion (holding all other variables constant/M.n 3 in Tab A2).

It is important to note, however, that the native comparison group may be rather heterogeneous here in their attitudes toward abortion because of the country variation in policies as described in Section 2.3. Women and men of the Turkish second generation differ in their attitudes from the average of the European natives. According to the literature, however, this is because the citizens in each European 
Fig. 2: Attitudes toward abortion in Turkish second generation relative to native comparison group, by reason and country

A - Medical reasons

Average marginal effects (AME)

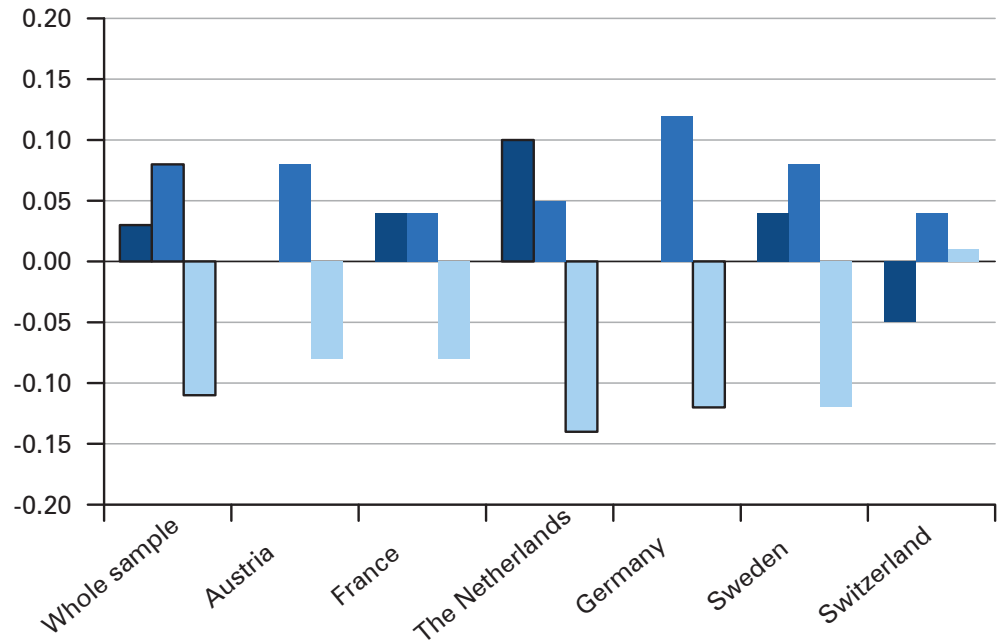

B - Non-medical reasons

Average marginal effects (AME)

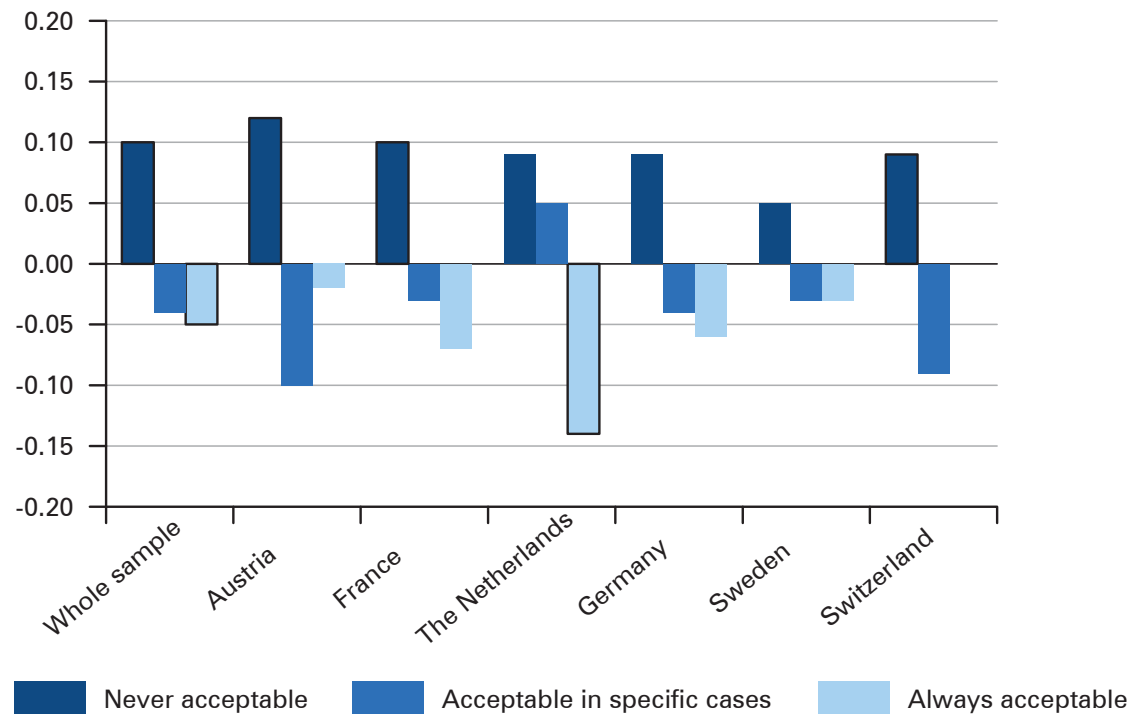

Results of multinomial logistic regression models, reference: native comparison group.

Controlled for sex, siblings, mothers' LFP, father's education, religious education, age, education, marital status, parenthood, religiosity, third-party presence.

Bars in black frames indicate significant differences at 5 percent.

Source: Own calculations based on TIES 2007-08 
country hold more liberal values toward abortion as well as to sexual liberalization and gender equality compared to those in other regions of the world, despite some variation between European countries (Norris/Inglehart 2012).

When we explored the comparison between the second generation and natives within each individual country, the overall patterns were found in all six analyses (Fig. 2A and 2B): The chances that second-generation Turks would never accept abortion for medical reasons hardly varied from the attitude of natives. But Turks were more likely to say "in specific cases" and less likely to say "always" than natives. With regard to abortion for non-medical reasons, second-generation Turks were more likely to never accept abortion. It must be noted, however, that much of the group differences could be explained by the additional explanatory variables and by the fact that the sample size of the single countries is rather small. This certainly also contributed to rather large confidence intervals. Therefore, we refrain from overinterpreting these results.

\subsection{Country variation}

Second, we test our working hypothesis of cross-country variation within the second generation and within natives separately.

Figures 3A-D display the country variation in attitudes by reason for abortion and migrant background (the countries were ordered by the highest level of "always" accepting for medical reasons in the native comparison group). In each country and in both groupings, we found greater acceptance of abortion for medical than for non-medical reasons. Overall, the highest levels of "always" acceptance of abortion for medical and non-medical reasons were found in Sweden and France, corresponding to the lowest percentage of "never" acceptance. The lowest levels of "always" and the highest shares of "never" acceptance were found in Germany and in Switzerland.

In the second generation, country variation did appear but was less clear-cut. The percentages of Turkish women and men who said they always accept abortion followed roughly the same pattern as that of natives, albeit on a lower level: The second-generation Turks in Sweden and France were the most likely to say they always accept abortion for medical and for non-medical reasons; but the trends were similar in Switzerland when it comes to abortion for medical reasons. The attitudes expressed by Turkish migrant children in Germany were closer to those of their counterparts in Austria and the Netherlands. While the variation of "never" acceptance of abortion was moderate regarding medical reasons, it was larger for non-medical reasons. Again, the lowest percentage was found in Sweden; the highest rates of rejection were found in the second generation living in Germany, Austria and in the Netherlands.

Figures $4 \mathrm{~A}$ and $4 \mathrm{~B}$ provide the results of the multivariate analyses (AME) for medical reasons in which we study the second Turkish generation and the native comparison group separately. As it has the lowest levels of acceptance, Germany serves as the reference category. In the native comparison group, the respondents in all six countries show no significant difference in their "never" acceptance, when 
Fig. 3: Attitudes toward abortion, by reason, migrant status and country (\%)
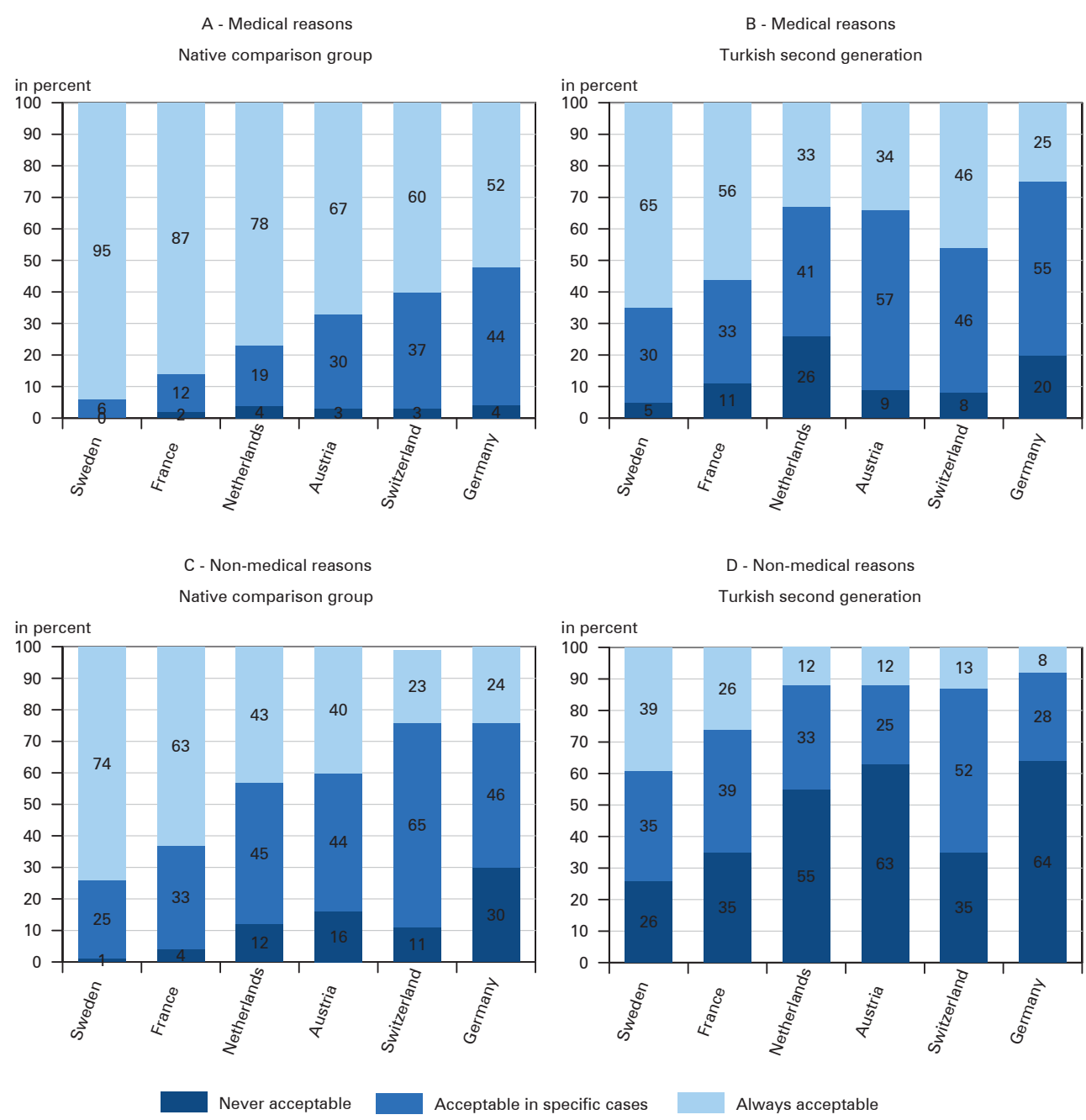

Source: Own calculations based on TIES 2007-08

we control for all other explanatory variables. The respondents in France and Sweden and - to a somewhat lesser degree - those in the Netherlands and Austria were significantly less likely to answer "in specific cases", but more likely to "always" accept abortion for medical reasons.

Looking at the second generation, we found a small but significant variation in the category "never", with those in Sweden, France, Austria and Switzerland less likely to reject abortion than those in Germany and in the Netherlands. Compared to the women and men of Turkish ancestry living in Germany, those in the other five countries answered "always" more often. 
Fig. 4: Attitudes toward abortion, by reason, migrant status and country (AME)

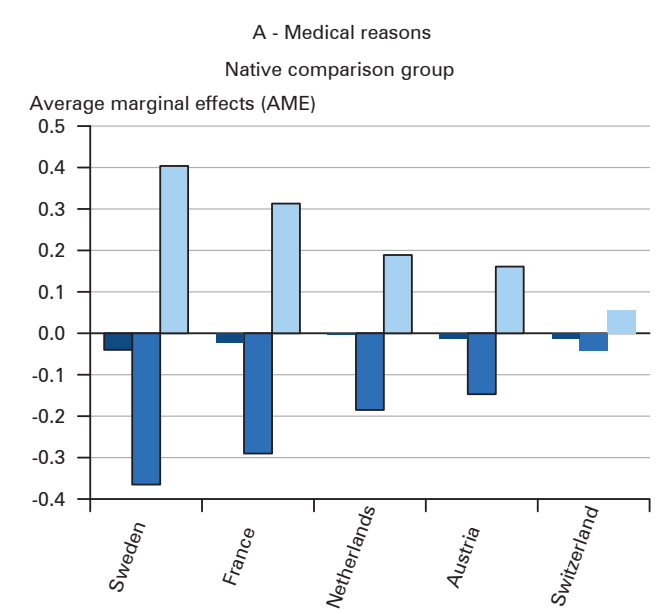

C - Non-medical reasons Native comparison group Average marginal effects (AME)

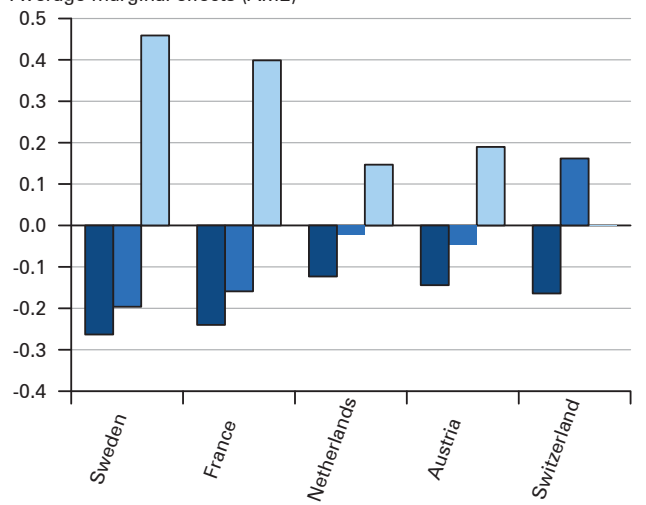

B - Medical reasons

Turkish second generation Average marginal effects (AME)

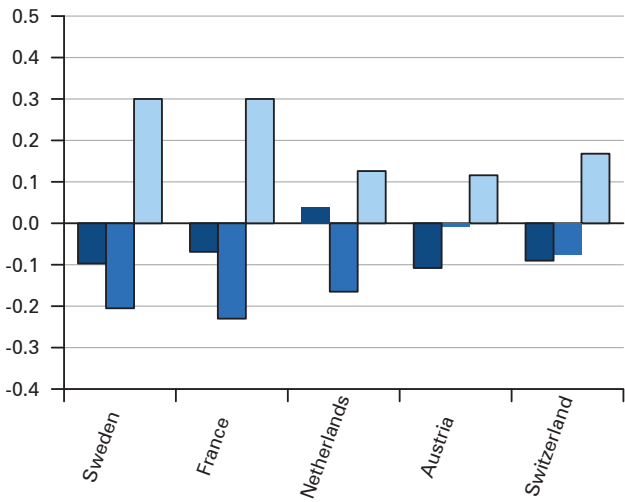

D - Non-medical reasons Turkish second generation

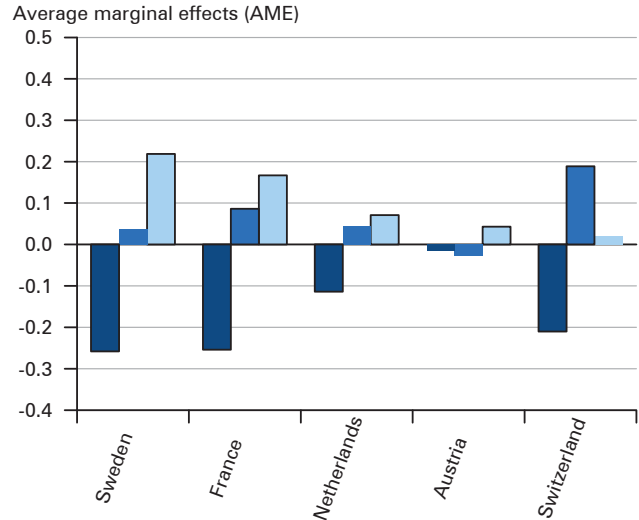

Never acceptable

Always acceptable

Results of multinomial logistic regression models, reference: Germany.

Controlled for sex, siblings, mothers' LFP, father's education, religious education, age, education, marital status, parenthood, religiosity, third-party presence.

Bars in black frames indicate significant differences at 5 percent.

Source: Own calculations based on TIES 2007-08

Figures $4 \mathrm{C}$ and $4 \mathrm{D}$ display the country results of the multivariate analyses for non-medical reasons. Compared to Germany, the persons in all other countries were significantly less likely to "never" accept abortion. Sweden and France stood out as having high shares of respondents who said they would always accept abortion; and there was less likelihood of "never" and "in specific cases" than in the other countries. 
In the second Turkish generation, the country variation was less pronounced. A similarity to the patterns of the native comparison group was that those in France and Sweden were less likely to say "never" and more likely to say "always". Also second generation Turks in the other three countries were more "liberal" than those in Germany - either by stating "in specific cases" more often (as is the case with those in Switzerland), or by being more likely to answer "always" (as is the case with those in the Netherlands or Austria).

\subsection{The role of the explanatory variables}

Coming back to our third hypothesis, we look at the effects of the socio-demographic controls and the socialisation context of the family. The independent variables did not contribute much to explaining the variation within the groupings under study, neither between the native comparison group and the second Turkish generation (Table A2 in the Appendix) nor within natives or Turks (Tables 2A and 2B).

In the Turkish second generation, religious upbringing (Koran school attendance) had an influence on attitudes toward abortion for medical reasons and non-medical reasons, i.e. lower "in specific cases" and "always" acceptance. Having 3+ siblings and the father's primary education were associated with lower acceptance of abortion.

Among the variables referring to the respondents' socio-economic situation at the time of the interview, tertiary education was associated with higher acceptance and primary education with lower acceptance of abortion for both types of reasons, compared to secondary schooling. Those who considered themselves religious said less often that they accepted abortion "in specific cases" or "always". Being married and carrying out the interview in the presence of a third person were also associated with lower levels of acceptance. These trends were similar to those in the native comparison group, albeit with smaller coefficient sizes.

\section{Discussion}

We analysed attitudes toward abortion among Turkish descendants living in six European countries, and compared them to the attitudes of their counterparts with non-migrant parents. Based on the assimilation theory, we had hypothesised that we would observe a gap between the second Turkish generation and the native comparison group. We did indeed find such a gap in our results: overall, the migrant descendants were less approving of abortion than the natives. But, as expected, the size of this gap varied depending on the reason for abortion. The differences between the second generation and the comparison group were smaller for abortion for medical reasons than for non-medical reasons. Moreover, we had hypothesised that this gap would diminish when we controlled for the socio-demographic composition of the groupings and further variables of the family background and childhood of the respondents. Our results only partially supported this hypothesis, because the differences between the groupings could be partially explained by the controls. 


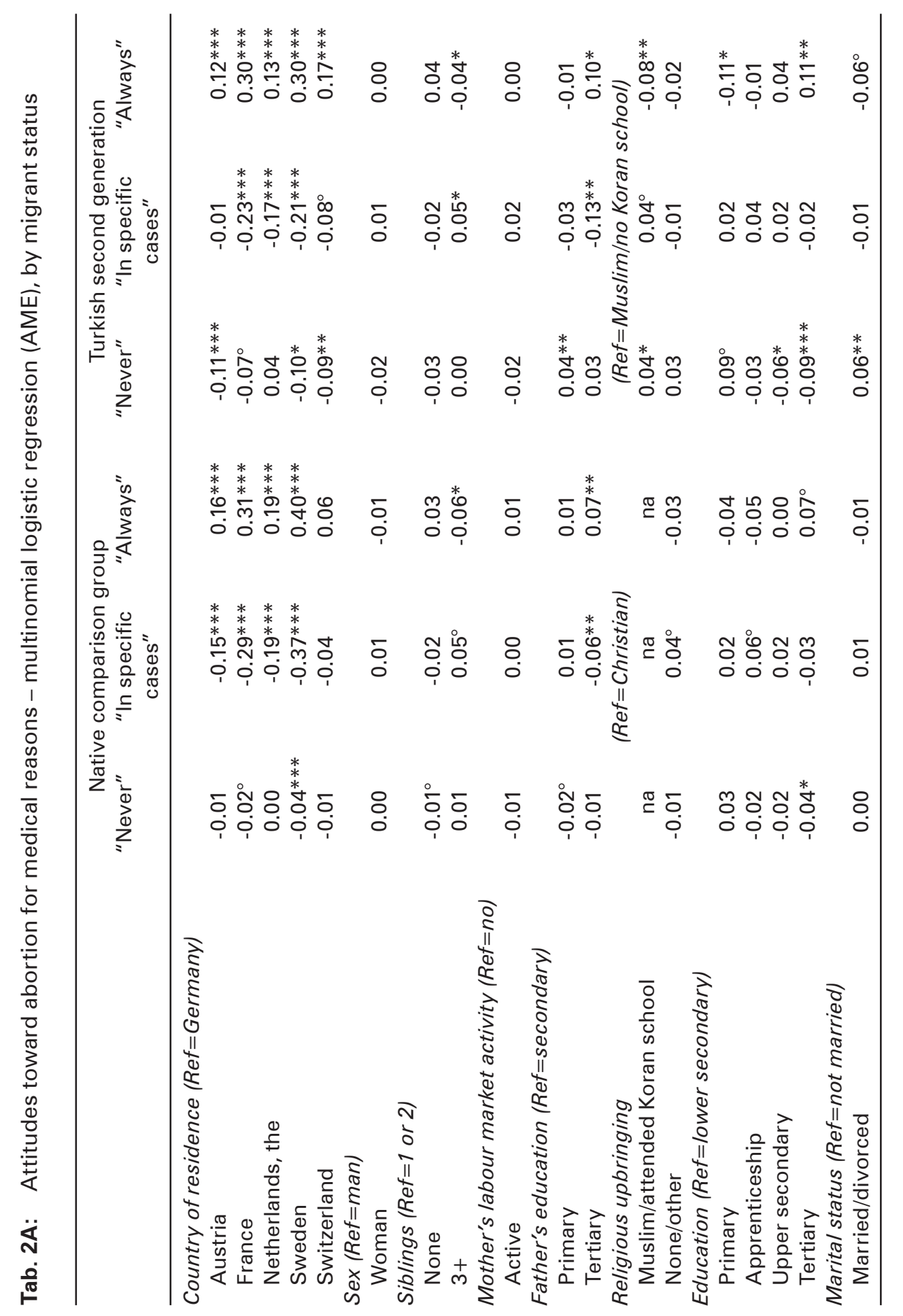




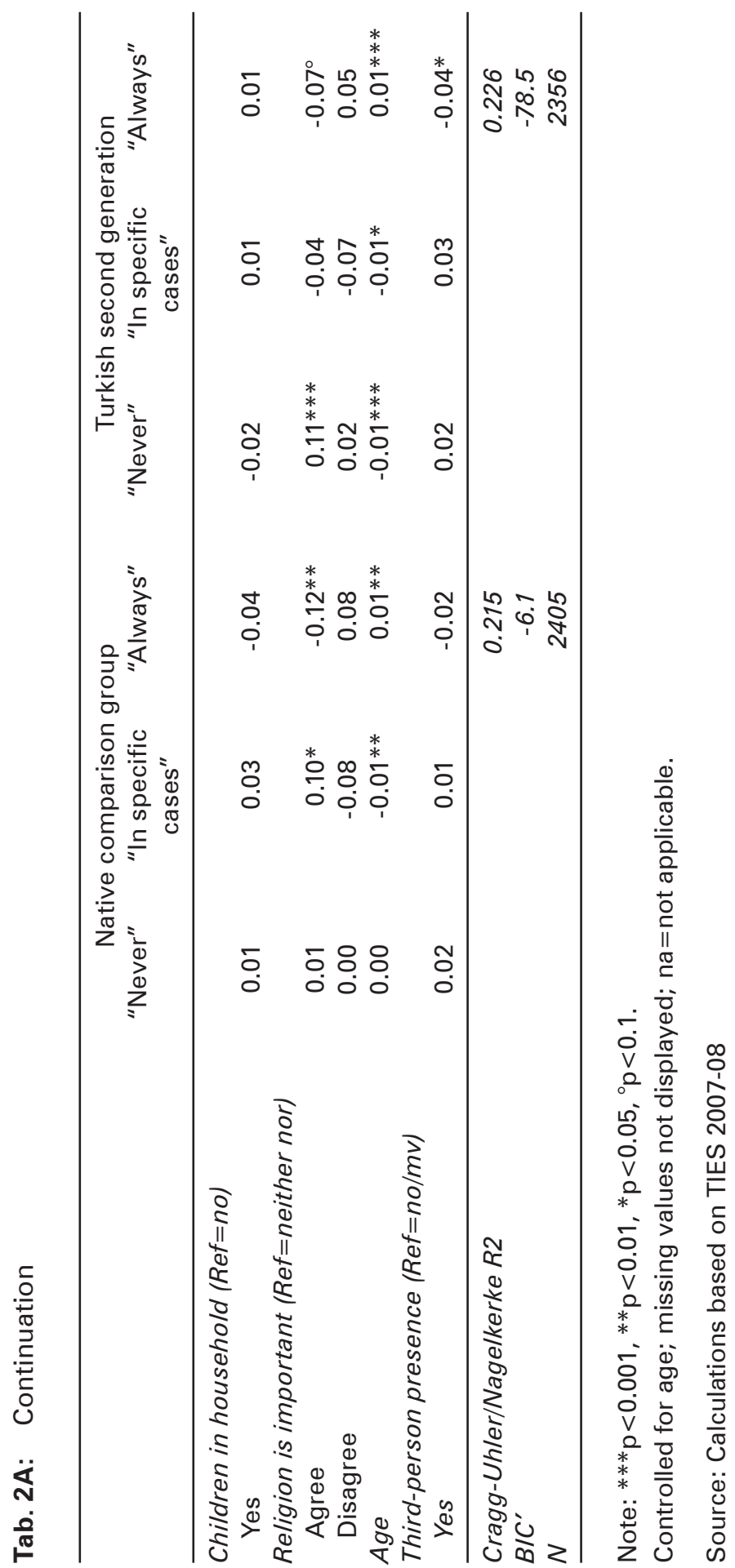




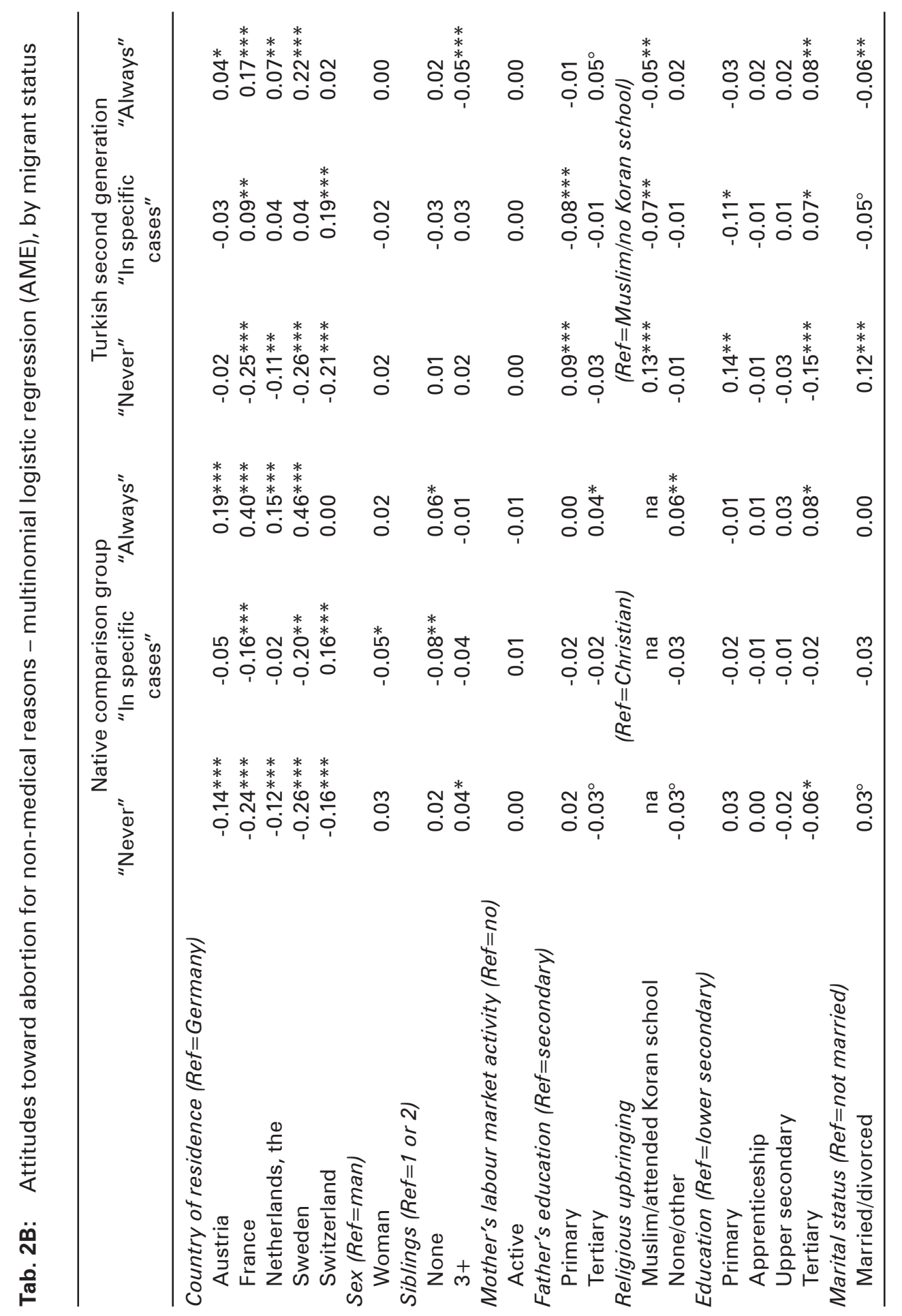




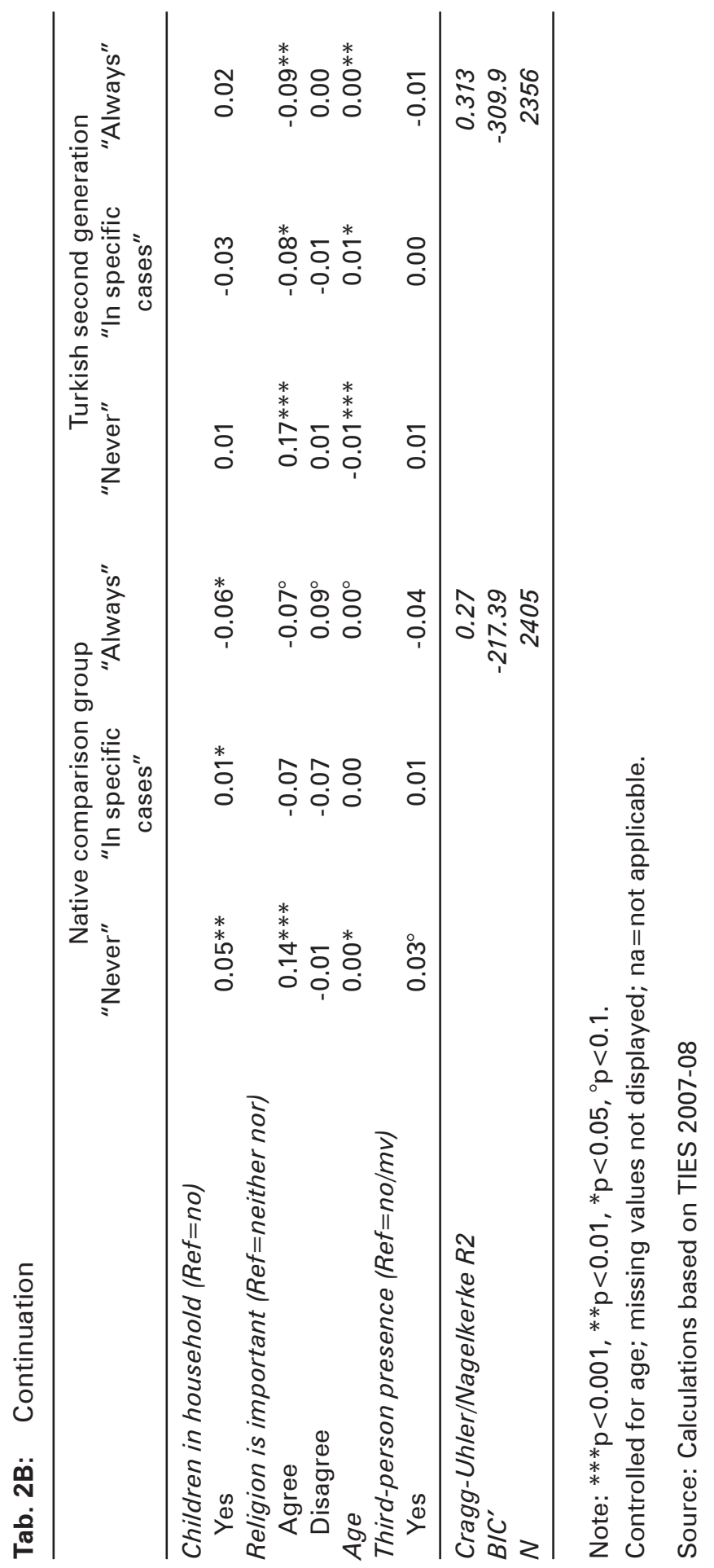


However, as significant differences remained, we cannot conclude that ideational assimilation occurred within one migrant generation.

Our second working hypothesis referred to country variation. We had expected to find that the respondents in Sweden, France and the Netherlands were the most accepting of abortion, and that those in Germany were the least accepting. Indeed, the respondents of the native comparison group by and large followed this pattern. Moreover, the patterns among the second generation were similar, although the differences between the countries were less pronounced. These results imply that the societal context plays a role in shaping the cultural assimilation processes of immigrants and their descendants.

The family of origin and the socio-demographic characteristics of the migrants and the subsequent generations were, however, important. Among the explanatory variables we used, education and religiosity stood out as determinants of attitudes toward abortion. The higher the education of the respondents, the more accepting they were of abortion. The religious education received during childhood exerted an influence on current attitudes, even when controlling for present religiosity. The higher the level of religious education was during childhood - i.e. when Turkish descendants attended Koran school in addition to receiving religious education at home - the lower their acceptance of abortion. These findings indicate that the socialisation context of the family of origin has a long-lasting impact on the ideational assimilation of migrant descendants.

It appears that compared to the pace at which they adopt other attitudes, such as attitudes regarding gender equality, second-generation migrants acculturate rather slowly to the dominant views on abortion in the destination country. One of the reasons might be that Turkish descendants lack a clear reference group. The topic of abortion does not lead to tension between the migrants' countries of origin and of destination; attitudes toward abortion are also among the most controversial issues within societies. Our results demonstrate that even among the native comparison groups in European countries, attitudes toward abortion vary widely. For example, while only a very small percentage of natives said they would never approve of abortion for medical reasons, the remainder were divided into one-third who said they would accept it in specific cases and two-thirds who said they would always accept it. The natives' levels of acceptance of abortion for non-medical reasons were lower overall, and the percentages of those who said they would accept it in specific cases or always were almost equal. We should also bear in mind that because the TIES sample was drawn from cities only, the levels of acceptance of abortion among natives may be overestimated. Hence, in this context, finding the reference point for adaptation processes among immigrants in Europe is not as straightforward as it is for indicators of structural integration and modernisation such as education. The group to which the second generation adapts therefore remains open.

Another reason for the comparatively slow pace of cultural assimilation may be that the signals sent in the receiving contexts are contradictory. In some societies, such as Germany, the policies regulating abortion may not fully align with public discourse about these issues. Germany has the most liberal abortion regulations among the countries we studied when it comes to reasons for abortion, and it is 
one of the countries in our sample where abortion is legal for non-medical reasons. In practice, however, access to abortion is highly contested in Germany, as women are required to seek counselling, and doctors who perform abortions are discredited in the political/public debate. While it is legal to perform abortions, physicians are not allowed to publicly list "abortion" among their services. If they do, they are punished - as the present-day debate shows. ${ }^{4}$

Knowledge of abortion options is, however, crucial to women's health. Such information is even more important for immigrants, as their knowledge of the host country's language and health care institutions and regulations may be less than that of the majority population. In the countries in our study where religiosity is lower and support for sexual liberalisation and gender equality is higher (France, Sweden, the Netherlands) - and these attitudes are reflected in policies - the views on abortion of migrant descendants were more liberal as those of natives.

A higher overall level of acceptance of abortion does not, however, mean that the residents of Europe generally approve of abortion. While few reject abortion in all cases, the remainder are divided over whether they would "always" accept it, or "in specific cases" only. We may speculate here that given the availability of modern methods of family planning and contraception, abortion is seen as the very last option for fertility control. Abortion and contraception have been found to be complementary (Miller/Valente 2016). Hence, future research on migrant fertility and integration should also look at knowledge about and the use of contraception. Access to both contraception and abortion are reproductive rights that are central to women's self-determination and gender equality. If migrant women - especially those from countries with patriarchal family systems - are to gain access to equal opportunities (even gradually over generations), this topic deserves special attention in policies, education and research on gender equality and public health.

Thus, if we want to understand processes of cultural integration among migrants, we should also pay attention to the topic of abortion, which is crucial to maternal and perinatal health (Canning/Schultz 2012). Because of socio-economic inequalities in the prevalence of induced abortion and its health risks (Ankara 2017), abortion is also an issue that arises in discussions of inequality between social/ ethnic groups.

\section{References}

Adamczyk, Amy 2013: The effect of personal religiosity on attitudes toward abortion, divorce, and gender equality - does cultural context make a difference? In: EurAmerica: A Journal of European and American Studies 43,1: 213-253.

Agadjanian, Victor; Yoo, Sam H. 2018: Migration, legality, and fertility regulation: Abortion and contraception among migrants and natives in Russia. In: Demographic Research 38,42: 1277-1302 [doi: 10.4054/DemRes.2018.38.42].

4 http://www.spiegel.de/politik/deutschland/jens-spahn-ueber-abtreibungen-es-geht-um-ungeborenes-menschliches-leben-a-1198661.html, SPIEGEL online, 11 April 2018. 
Alba, Richard; Kasinitz, Philip; Waters, Mary C. 2011: The kids are (mostly) alright: Second-generation assimilation. In: Social Forces 89,3: 763-774 [doi: 10.1353/ sof.2011.0024].

Alba, Richards; Nee, Victor 1997: Rethinking assimilation theory for a new era of immigration. In: The International Migration Review 31,4: 826-874 [doi: 10.2307/2547416].

Alba, Richard; Nee, Victor 2003: Remaking the American mainstream: Assimilation and contemporary immigration. Cambridge: Harvard University Press.

Almond, Douglas; Edlund, Lena; Milligan, Kevin 2013: Son preference and the persistence of culture: Evidence from South and East Asian immigrants to Canada. In: Population and Development Review 39,1: 75-95 [doi: 10.1111/j.1728-4457.2013.00574.x].

Almond, Gabriel A.; Verba, Sidney 1989: The civic culture: Political attitudes and democracy in five nations. New ed. Newbury Park, CA: Sage Publications.

Andersson, Gunnar; Scott, Kirk 2005: Labour-market status and first-time parenthood: the experience of immigrant women in Sweden, 1981-97. In: Population Studies 59,1: 21-38 [doi: 10.1080/0032472052000332683].

Ankara, Hasan Giray 2017: Socioeconomic variations in induced abortion in Turkey. In: Journal of Biosocial Science 49,1: 99-122 [doi: 10.1017/S0021932016000158].

Arisi, Emilio 2003: Changing attitudes towards abortion in Europe. In: The European Journal of Contraception \& Reproductive Health Care 8,2: 109-121 [doi: 10.1080/ ejc.8.2.109.121].

Bahr, Stephen J.; Marcos, Anastasios C. 2003: Cross-cultural attitudes toward abortion. In: Journal of Family Issues 24,3: 402-424 [doi: 10.1177/0192513X02250892].

Bandura, Albert 1977: Social learning theory. New York: General Learning Press.

Bankole, Akinrinola; Singh, Susheela; Haas, Taylor 1998: Reasons why women have induced abortions: Evidence from 27 countries. In: International Family Planning Perspectives 24,3: 117-127 \& 152.

Baykara-Krumme, Helen; Milewski, Nadja 2017: Fertility patterns among Turkish women in Turkey and abroad: The effects of international mobility, migrant generation, and family background. In: European Journal of Population 33,3: 409-436 [doi: 10.1007/ s10680-017-9413-9].

Bozon, Michel; Héran, Francois 2006: La formation du couple: textes essentiels pour la sociologie de la famille. Paris: La De'couverte, coll. Grands Repe`res. Classiques.

Bumpass, Larry L. 1997: The measurement of public opinion on abortion: The effects of survey design. In: Family Planning Perspectives 29,4: 177-180 [doi: 10.2307/2953382].

Canning, David; Schultz, Paul 2012: The economic consequences of reproductive health and family planning. In: The Lancet 380: 165-171 [doi: 10.1016/S0140-6736(12)60827-7].

Carol, Sarah; Ersanilli, Evelyn; Wagner, Mareike 2014: Spousal choice among the children of Turkish and Moroccan immigrants in six European countries: Transnational spouse or co-ethnic migrant? In: International Migration Review 48,2: 387-414 [doi: 10.1111/imre.12068]

Carol, Sarah; Helbling, Marc; Michalowski, Ines 2015: A struggle over religious rights? How Muslim immigrants and Christian natives view the accommodation of religion in six European countries. In: Social Forces 94,2: 647-671 [doi: 10.1093/sf/sov054].

Carol, Sarah; Milewski, Nadja 2017: Attitudes toward abortion among the Muslim minority and non-Muslim majority in cross-national perspective: Can religiosity explain the differences? In: Sociology of Religion 78,4: 456-491 [doi: 10.1093/socrel/srx015]. 
Cifuentes, Isabel Valdés; Wagner, Michael; Naderi, Robert 2013: Heirat und Familiengründung bei Deutschen und türkischstämmigen Personen in Deutschland. In: Kölner Zeitschrift für Soziologie und Sozialpsychologie 65,3: 479-504 [doi: 10.1007/s11577013-0214-9].

Clements, Ben 2015: Religion and public opinion in Britain: Continuity and change. Basingstoke: Palgrave Macmillan.

Crul, Maurice et al. 2012: School careers of second-generation youth in Europe. Which education systems provide the best chances for success? In: Crul, Maurice; Schneider, Jens; Lelie, Frans (Eds.): The European second generation compared. Does the integration context matter? Amsterdam: AUP: 101-158 [doi: 10.1515/9789048516926006].

Diehl, Claudia; Koenig, Matthias 2009: Religiosität türkischer Migranten im Generationenverlauf: Ein Befund und einige Erklärungsversuche. In: Zeitschrift für Soziologie 38,4: 300-319 [doi: 10.1515/zfsoz-2009-0403].

Ersanilli, Evelyn; Koopmans, Ruud 2011: Do immigrant integration policies matter? A three-country comparison among Turkish immigrants. In: West European Politics 34,2: 208-234 [doi: 10.1080/01402382.2011.546568].

Ersanilli, Evelyn 2012: Model(ling) citizens? Integration policies and value integration of Turkish immigrants and their descendants in Germany, France, and the Netherlands. In: Journal of Immigrant \& Refugee Studies 10,3: 338-358 [doi: 10.1080/15562948.2012.693336]

ESHRE CapriWorkshop Group 2015: “Emergency contraception. Widely available and effective but disappointing as a public health intervention: A review." In: Human Reproduction 30,4: 751-60 [doi: 10.1093/humrep/dev019].

Foner, Nancy 1997: The immigrant family: Cultural legacies and cultural change. In: The International Migration Review 31,4: 961-974 [doi: 10.2307/2547420].

Foner, Nancy; Alba, Richards 2008: Immigrant religion in the U.S. and Western Europe: Bridge or barrier to inclusion? In: International Migration Review 42,2: 360-392 [doi: 10.1111/j.1747-7379.2008.00128.x].

Garssen, Joop; Nicolaas, Han 2008: Fertility of Turkish and Moroccan women in the Netherlands: Adjustment to native level within one generation. In: Demographic Research 19,33: 1249-1280 [doi: 10.4054/DemRes.2008.19.33].

Gerhards, Jürgen; Rucht, Dieter 2000: Öffentlichkeit, Akteure und Deutungsmuster: Die Debatte über Abtreibungen in Deutschland und den USA. In: Gerhards, Jürgen (Ed.): Die Vermessung kultureller Unterschiede. Wiesbaden: VS Verlag für Sozialwissenschaften: 165-188 [doi: 10.1007/978-3-322-90239-9_9].

Goodman, Sara W.; Wright, Matthew 2015: Does mandatory integration matter? Effects of civic requirements on immigrant socio-economic and political outcomes. In: Journa of Ethnic and Migration Studies 41,2: 1885-1908 [doi: 10.1080/1369183X.2015.1042434].

Gordon, Milton M. 1964: Assimilation in American life: The role of race, religion, and national origins. New York: Oxford University Press.

Groenewald, George; Lessard-Phillips, Laurence 2012: Research methodology. In: Crul, Maurice; Schneider, Jens; Lelie, Frans (Eds.): The European second generation compared. Does the integration context matter? Amsterdam: AUP: 39-56 [doi: 10.1515/9789048516926-004].

Hamel, Christel et al. 2012: Union formation and partner choice. In: Crul, Maurice; Schneider, Jens; Lelie, Frans (Eds.): The European second generation compared. Does the integration context matter? Amsterdam: AUP: 225-284 [doi: 10.1515/9789048516926008]. 
Haub, Carl 2007: Kontrazeption weltweit [http://www.berlin-institut.org/fileadmin/user_ upload/handbuch_texte/pdf_Haub_Kontrazeption_weltweit.pdf, 17.04.2018].

Hedayat, Kamyar M.; Shooshtarizadeh, P.; Raza, Mohsin 2006: Therapeutic abortion in Islam: Contemporary views of Muslim Shiite scholars and effect of recent Iranian legislation. In: Journal of Medical Ethics 32,11: 652-657 [doi: 10.1136/jme.2005.015289].

Helfferich, Cornelia; Klindworth, Heike; Kruse, Jan 2011: Frauen Leben: Familienplanung und Migration im Lebenslauf. Eine Studie im Auftrag der Bundeszentrale für gesundheitliche Aufklärung (BZgA). Köln.

Inglehart, Ronald F.; Norris, Pippa 2003: Rising tide. Gender equality and cultural change around the world. Cambridge: Cambridge University Press [doi: 10.1017/ CBO9780511550362].

Jacob, Konstanze; Kalter, Frank 2013: Intergenerational change in religious salience among immigrant families in four European countries. In: International Migration 51,3: 38-56 [doi: 10.1111/imig.12108].

Jelen, Ted G. 2014: The subjective bases of abortion attitudes: A cross national comparison of religious traditions. In: Politics and Religion 7,3: 550-567 [doi: 10.1017/ S1755048314000467].

Jelen, Ted G.; Wilcox, Clyde 2003: Causes and consequences of public attitudes toward abortion: A review and research agenda. In: The Western Political Quarterly 56,4: 489 500 [doi: 10.1177/106591290305600410].

Kalmijn, Matthijs; Kraaykamp, Gerbert 2017: Determinants of cultural assimilation in the second generation. A longitudinal analysis of values about marriage and sexuality among Moroccan and Turkish migrants. In: Journal of Ethnic and Migration Studies 44,5: 697-717 [doi: 10.1080/1369183X.2017.1363644].

Koenig, Matthias; Maliepaard, Mieke; Güveli, Ayse 2016: Religion and new immigrants' labor market entry in Western Europe. In: Ethnicities 16,2: 213-235 [doi: 10.1177/1468796815616159].

Koopmans, Ruud 2015: Religious fundamentalism and hostility against out-groups: A comparison of Muslims and Christians in Western Europe. In: Journal of Ethnic and Migration Studies 41,1: 33-57 [doi: 10.1080/1369183X.2014.935307].

Krapf, Sandra; Wolf, Katharina 2015: Persisting differences or adaptation to German fertility patterns? First and second birth behavior of the 1.5 and second generation Turkish migrants in Germany. In: Kölner Zeitschrift für Soziologie und Sozialpsychologie 67, Supplement 1: 137-164 [doi: 10.1007/s11577-015-0331-8].

Kulu, Hill; González-Ferrer, Amparo 2014: Family dynamics among immigrants and their descendants in Europe: Current research and opportunities. In: European Journal of Population 30,4: 411-435 [doi: 10.1007/s10680-014-9322-0].

Levels, Mark; Sluiter, Roderick; Need, Ariana 2014: A review of abortion laws in Western-European countries. A cross-national comparison of legal developments between 1960 and 2010. In: Health Policy 118,1: 95-104 [doi: 10.1016/j.healthpol.2014.06.008].

Lewis, Valerie A.; Kashyap, Ridhi 2013: Are Muslims a distinctive minority? An empirical analysis of religiosity, social attitudes, and Islam. In: Journal for the Scientific Study of Religion 52,3: 617-626 [doi: 10.1111/jssr.12044].

Loeber, Olga 2008: Sexual and reproductive health issues of Turkish immigrants in the Netherlands. In: The European Journal of Contraception \& Reproductive Health Care 13,4: 330-338 [doi: 10.1080/13625180802303626]. 
Milewski, Nadja 2007: First child of immigrant workers and their descendants in West Germany: Interrelation of events, disruption, or adaptation? In: Demographic Research 17: 859-896 [doi: 10.4054/DemRes.2007.17.29].

Milewski, Nadja 2010a: Immigrant fertility in West Germany: Is there a socialization effect in transitions to second and third births? In: European Journal of Population 26,3: 297-323 [doi: 10.1007/s10680-010-9211-0].

Milewski, Nadja 2010b: Fertility of Immigrants. A two-generational approach in Germany. Berlin/Heidelberg: Springer Verlag [doi: 10.1007/978-3-642-03705-4].

Milewski, Nadja 2011: Transition to a first birth among Turkish second-generation migrants in Western Europe. In: Advances in Life Course Research 16,4: 178-189 [doi: 10.1016/j.alcr.2011.09.002].

Milewski, Nadja; Otto, Danny 2017: The presence of a third person in face-to-face interviews with immigrant descendants: Patterns, determinants, and effects. In: Bolzman, Claudio; Bernardi, Laura; Le Goff, Jean-Marie (Eds.): Situating children of migrants across borders and origins. A methodological overview. Dordrecht: Springer: 77-96 [doi: 10.1007/978-94-024-1141-6_4].

Miller, Grant; Valente, Christine 2016: Population policy: Abortion and modern contraception are substitutes. In: Demography 53,4: 979-1009 [doi: 10.1007/s13524-0160492-8].

Mood, Carina 2010: Logistic regression: Why we cannot do what we think we can do, and what we can do about it. In: European Sociological Review 26,1: 67-82 [doi. 10.1093/ esr/jcp006].

Murphy, Michael; Wang, Duolao 2001: Family-level continuities in childbearing in low-fertility societies. In: European Journal of Population 17,1: 75-96 [doi. 10.1023/A:1010744314362].

Nauck, Bernhard 1997: Sozialer Wandel, Migration und Familienbildung bei türkischen Frauen. In: Nauck, Bernhard; Schönpflug, Ute (Eds.): Familien in verschiedenen Kulturen. Stuttgart: Ferdinand Enke Verlag: 162-199.

Norris, Pippa; Inglehart, Ronald F. 2012: Muslim integration into Western cultures: Between origins and destinations. In: Political Studies 60,2: 228-251 [doi: 10.1111/j.14679248.2012.00951.x].

Nosaka, Akiko; Chasiotis, Athanasios 2010: Parental influence on fertility behavior of first generation Turkish immigrants in Germany. In: Journal of Immigrant and Minority Health 12,1: 60-67 [doi: 10.1007/s10903-008-9172-0].

Ribbert, Bärbel 2009: Erfahrungen aus dem Familienplanungszentrum Hamburg: Migrantinnen aus westafrikanischen Herkunftsländern. In: Bundeszentrale für gesundheitliche Aufklärung (Ed.): Migration und Gesundheitsförderung. Ergebnisse einer Tagung mit Expertinnen und Experten. Köln: 101-115.

Röder, Antje 2014: Explaining religious differences in immigrants' gender role attitudes: the changing impact of origin country and individual religiosity. In: Ethnic and Racial Studies 37,14: 2615-2635 [doi: 10.1080/01419870.2013.854919].

Röder, Antje; Mühlau, Peter 2014: Are they acculturating? Europe's immigrants and gender egalitarianism. In: Social Forces 92,3: 899-928 [doi: 10.1093/sf/sot126].

Rosenhouse-Persson, Sandra; Sabagh, Georges 1983: Attitudes toward abortion among catholic Mexican-American women: The effects of religiosity and education. In: Demography 20,1: 87-98 [doi: 10.2307/2060903]. 
Rydgren, Jens 2005: Is extreme right-wing populism contagious? Explaining the emergence of a new party family. In: European Journal of Political Research 44,3: 413-437 [doi: 10.1111/j.1475-6765.2005.00233.x].

Saroglou, Vassilis 2011: Believing, bonding, behaving, and belonging: The big four religious dimensions and cultural variation. In: Journal of Cross-Cultural Psychology 42,8: 1320-1340 [doi: 10.1177/0022022111412267].

Sedgh, Gilda et al. 2016: Abortion incidence between 1990 and 2014: global, regional, and subregional levels and trends. In: The Lancet 388,10041: 258-267 [doi 10.1016/ S0140-6736(16)30380-4].

Shapiro, Gilla K. 2014: Abortion law in Muslim-majority countries: An overview of the Islamic discourse with policy implications. In: Health Policy and Planning 29,4: 483494 [doi: 10.1093/heapol/czt040].

Sniderman, Paul M.; Hagendoorn, Louk 2007: When ways of life collide: Multiculturalism and its discontents in the Netherlands. Princeton: Princeton University Press.

Soehl, Thomas 2016: From origins to destinations: acculturation trajectories in migrants attitudes towards homosexuality. In: Journal of ethnic and Migration Studies 43,11: 1831-1853 [doi: 10.1080/1369183X.2016.1246178].

Van de Kaa, Dirk J. 1987: Europe's second demographic transition. Population Bulletin 42,1: 1-59.

Van Tubergen, Frank; Sindradottir, Jórunn I. 2011: The religiosity of immigrants in Europe: A cross-national study. In: Journal for the Scientific Study of Religion 50,2: 272288 [doi: 10.1111/j.1468-5906.2011.01567.x].

Weichselbaumer, Doris 2016: Discrimination against female migrants wearing headscarves. In: IZA Discussion Paper Series 10217: 1-27.

Prof. Dr. Nadja Milewski $(\varangle)$. University of Rostock, Institute of Sociology and Demography. Rostock, Germany. E-mail: nadja.milewski@uni-rostock.de URL: https://www.isd.uni-rostock.de/en/isd/lehrstuhl/jp-demo/milewski/

Prof. Dr. Sarah Carol. University of Cologne, Institute of Sociology and Social Psychology (ISS). Cologne, Germany. E-mail: carol@wiso.uni-koeln.de

URL: https://www.iss-wiso.uni-koeln.de/en/institute/staff/c/prof-dr-sarah-carol/ 
Attitudes toward Abortion among the Turkish Second Generation in Europe

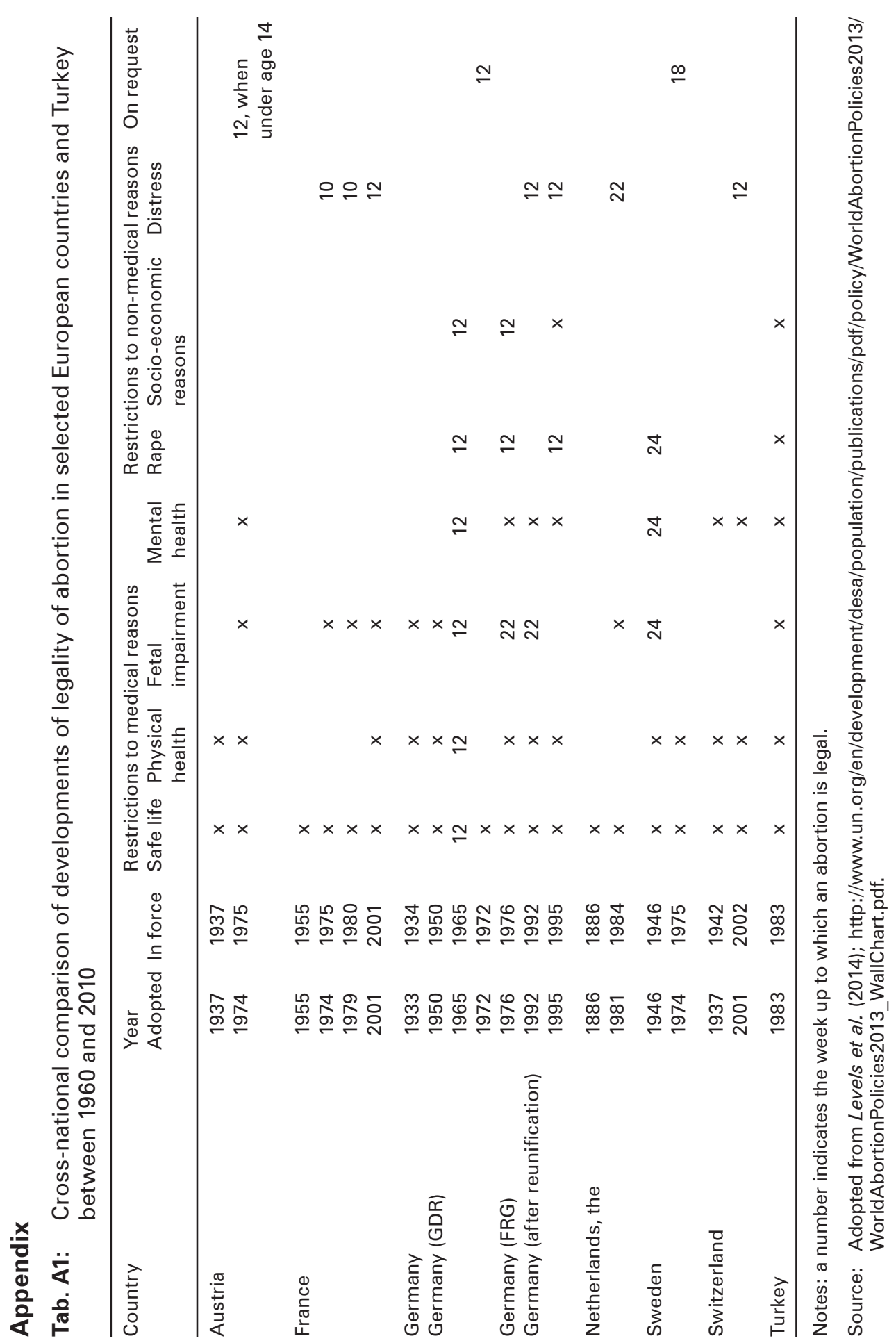


Tab. A2: Attitudes toward abortion in the Turkish second generation relative to native comparison group - multinomial logistic regression (AME)

\begin{tabular}{|c|c|c|c|c|c|c|}
\hline & \multicolumn{3}{|c|}{ For medical reasons } & \multicolumn{3}{|c|}{ For non-medical reasons } \\
\hline & M.m 1 & M.m 2 & M.m 3 & M.n 1 & M.n 2 & M.n 3 \\
\hline \multicolumn{7}{|l|}{$\begin{array}{l}\text { Six countries (pooled sample) } \\
(\mathrm{N}=4761)\end{array}$} \\
\hline Never acceptable & $0.12 * * *$ & $0.06 * * *$ & $0.03^{*}$ & $0.35^{* * *}$ & $0.16 * * *$ & $0.10^{* * *}$ \\
\hline Acceptable in specific cases & $0.18 * * *$ & $0.12 * * *$ & $0.08^{* *}$ & $-0.11 * * *$ & $-0.05^{*}$ & -0.04 \\
\hline Always acceptable & $-0.30 * * *$ & $-0.18 * * *$ & $-0.11 * * *$ & $-0.24 * * *$ & $-0.11 * * *$ & $-0.05^{* *}$ \\
\hline \multicolumn{7}{|l|}{ Single-country analyses } \\
\hline \multicolumn{7}{|l|}{ Austria } \\
\hline Never acceptable & $0.06^{* * *}$ & 0.01 & 0.00 & $0.47^{* * *}$ & $0.17^{*}$ & $0.12^{\circ}$ \\
\hline Acceptable in specific cases & $0.27 * * *$ & 0.11 & 0.08 & $-0.19 * * *$ & $-0.12^{\circ}$ & -0.10 \\
\hline Always acceptable & $-0.33^{* * *}$ & $-0.12^{\circ}$ & -0.08 & $-0.28 * * *$ & $-0.11 * * *$ & -0.02 \\
\hline \multicolumn{7}{|l|}{ France } \\
\hline Never acceptable & $0.09 * * *$ & $0.06^{* *}$ & 0.04 & $0.31 * * *$ & $0.15^{* *}$ & $0.10^{*}$ \\
\hline Acceptable in specific cases & $0.21 * * *$ & $0.10^{\circ}$ & 0.04 & $0.06^{\circ}$ & 0.02 & -0.03 \\
\hline Always acceptable & $-0.31 * * *$ & $-0.16 * *$ & -0.08 & $-0.37 * * *$ & -0.05 & -0.07 \\
\hline \multicolumn{7}{|l|}{ Netherlands, the } \\
\hline Never acceptable & $0.22 * * *$ & $0.16 * * *$ & $0.10^{*}$ & $0.43^{* * *}$ & $0.22 * * *$ & 0.09 \\
\hline Acceptable in specific cases & $0.22 * * *$ & $0.16^{*}$ & 0.05 & $-0.12 * * *$ & 0.01 & 0.05 \\
\hline Always acceptable & $-0.44 * * *$ & $-0.31 * * *$ & $-0.14^{*}$ & $-0.31 * * *$ & $-0.23^{* * *}$ & $-0.14^{*}$ \\
\hline \multicolumn{7}{|l|}{ Germany } \\
\hline Never acceptable & $0.16 * * *$ & 0.00 & 0.00 & $0.34 * * *$ & 0.09 & 0.09 \\
\hline Acceptable in specific cases & $0.11 * * *$ & $0.13^{\circ}$ & 0.12 & $-0.18^{* * *}$ & -0.02 & -0.04 \\
\hline Always acceptable & $-0.28 * * *$ & $-0.13^{*}$ & $-0.12^{\circ}$ & $-0.16 * * *$ & -0.07 & -0.06 \\
\hline \multicolumn{7}{|l|}{ Sweden } \\
\hline Never acceptable & $0.05^{* *}$ & 0.04 & 0.04 & $0.25^{* * *}$ & $0.13^{* *}$ & 0.05 \\
\hline Acceptable in specific cases & $0.24^{* * *}$ & $0.18^{* *}$ & 0.08 & $0.09^{\circ}$ & 0.03 & -0.03 \\
\hline Always acceptable & $-0.29 * * *$ & -0.22 & -0.12 & $-0.35^{* * *}$ & $-0.16^{*}$ & -0.03 \\
\hline \multicolumn{7}{|l|}{ Switzerland } \\
\hline Never acceptable & $0.05^{* *}$ & -0.04 & -0.05 & $0.24 * * *$ & $0.13^{*}$ & $0.09^{\circ}$ \\
\hline Acceptable in specific cases & $0.09^{*}$ & 0.07 & 0.04 & $-0.13^{* * *}$ & $-0.12^{\circ}$ & -0.09 \\
\hline Always acceptable & $-0.14^{* * *}$ & -0.03 & 0.01 & $-0.11 * * *$ & $-0.01 *$ & 0.00 \\
\hline
\end{tabular}

Note: ${ }^{* *} \mathrm{p}<0.001,{ }^{*} \mathrm{p}<0.01,{ }^{*} \mathrm{p}<0.05,{ }^{\circ} \mathrm{p}<0.1$.

Model 1 controlled for sex.

Model 2 additionally controlled for country of residence, siblings, mothers' LFP, father's education, religious education.

Model 3 additionally controlled for age, education, marital status, parenthood, religiosity, third-party presence.

Results of the Models 3 are displayed in Figures 2A and 2B.

M.m. = modell for medical reasons

M.n. = modell for non-medical reasons

Source: Own calculations based on TIES 2007-08 


\section{Comparative Population Studies}

WWW.comparativepopulationstudies.de

ISSN: 1869-8980 (Print) - 1869-8999 (Internet)

\section{Published by}

Prof. Dr. Norbert F. Schneider

Federal Institute for Population Research D-65180 Wiesbaden / Germany

\section{(cc) BY-SA}

2018

\section{Managing Editor}

Dr. Katrin Schiefer

\section{Copy Editor}

Dr. Evelyn Grünheid

Dr. Katrin Schiefer

\section{Editorial Assistant}

Beatriz Feiler-Fuchs

Wiebke Hamann

\section{Layout \\ Beatriz Feiler-Fuchs \\ E-mail:cpos@bib.bund.de}

\section{Scientific Advisory Board}

Karsten Hank (Cologne)

Michaela Kreyenfeld (Berlin)

Marc Luy (Vienna)

Peter Preisendörfer (Mainz)

Nikola Sander (Wiesbaden)

Zsolt Spéder (Budapest)

Rainer Wehrhahn (Kiel)

\section{Board of Reviewers}

Martin Abraham (Erlangen)

Laura Bernardi (Lausanne)

Hansjörg Bucher (Bonn)

Claudia Diehl (Konstanz)

Andreas Diekmann (Zurich)

Gabriele Doblhammer-Reiter (Rostock)

Jürgen Dorbritz (Wiesbaden)

Anette Eva Fasang (Berlin)

E.-Jürgen Flöthmann (Bielefeld)

Alexia Fürnkranz-Prskawetz (Vienna)

Beat Fux (Salzburg)

Joshua Goldstein (Berkeley)

Sonja Haug (Regensburg)

Hill Kulu (Liverpool)

Aart C. Liefbroer (The Hague)

Kurt Lüscher (Konstanz)

Emma Lundholm (Umeå)

Nadja Milewski (Rostock)

Dimiter Philipov (Vienna)

Roland Rau (Rostock)

Tomáš Sobotka (Vienna)

Jeroen Spijker (Barcelona)

Olivier Thévenon (Paris)

Helga de Valk (Brussels)

Heike Trappe (Rostock)

Michael Wagner (Cologne) 